\title{
Using a System Dynamics Model for Investigating Potential Levels of Antibiotics Pollution in the Volga River
}

\author{
Harald Ulrik Sverdrup • Liudmila L. Frolova • \\ Anthoniy Elias Sverdrup
}

Received: 26 November 2019 / Accepted: 12 March 2020 /Published online: 7 April 2020

(C) The Author(s) 2020

\begin{abstract}
We have modelled the possible antibiotics concentrations at different nodes along the Volga River using a system dynamics model developed for the purpose. The antibiotics concentrations in the river estimated using the model are far above the proposed no effect concentrations (PNEC) limits suggested by the WHO and EU European Environmental Agency at $0.1 \mu \mathrm{g} / 1$ total antibiotics water content. Concentrations in the range of 0.1 to more than $4 \mu \mathrm{g} / \mathrm{l}$ have been simulated with the model. A part of this comes from use in the agricultural sector. The simulations were done with a system dynamics model built for the purpose. The Volga model simulations are uncertain because of lack of measurements in the river and lack of accurate estimates of antibiotics loads from medical and agricultural use. The picture is consistent with observations in earlier international studies from various rivers in the world. To comply with the suggested PNEC limit, the medical pollution to Volga needs to be reduced by $90 \%$.
\end{abstract}

Keywords System dynamics · Volga River · Hydrology Antibiotics pollution · Drinking water quality

\section{H. U. Sverdrup $(\bowtie)$}

Department of Game Development - The Game School, Inland Norway University of Applied Sciences, Holsetgaten 31, 2301 Hamar, Norway

e-mail: hus@hi.is

L. L. Frolova · A. E. Sverdrup

Genetics and Bioinformatics, Kazan Federal University,

Kremlevskaya Street 18, Kazan 420 008, Russia

\section{Introduction}

Volga is the largest river in Europe and has about 65 million people living it its catchment. Cities with 30 million people rely on the Volga for their drinking water. The river is in the central part of Russia, and the health of Russia hangs together with the health of Volga (Fig. 1). The length of the Volga River is $3550 \mathrm{~km}$ from its origins in the Valdai Hills in the west, to the outflow in the Caspian Sea in the south. The catchment area is $1,380,000 \mathrm{~km}^{2}$, and the flow at the outlet to the Caspian Sea is $8060 \mathrm{~m}^{3} / \mathrm{s}$ on the average.

The Rybinsk Reservoir was built 1935-1941 and started filling 1941. The purpose was to provide a minimum sailing depth of $4.5 \mathrm{~m}$, control spring floods, and to produce large amounts of electric energy to support a the industrialization process of the Soviet Union. A huge populated area was flooded, the city of Mologa from the eleventh century and 166 surrounding villages all disappeared under water, and a huge population was displaced. In those days, the approach was very technical and less attention was paid to the social welfare of the population that got displaced in the process (Filtzer 2008). The Rybinsk lake surface area is about $4560 \mathrm{~km}^{2}$, he Rybinsk Reservoir water volume is $24.4 \mathrm{~km}^{3}$, average depth is about 5-6 m, the construction period lasted 1935-1947, and the reservoir started filling in 1942 and it was full by 1947 . The average flow at the outlet is about $600 \mathrm{~m}^{3} / \mathrm{s}$, and the water reservoir residence time on the average is about $1 / 3$ year. The largest tributaries are the Mologa River and the Upper Volga rivers. 


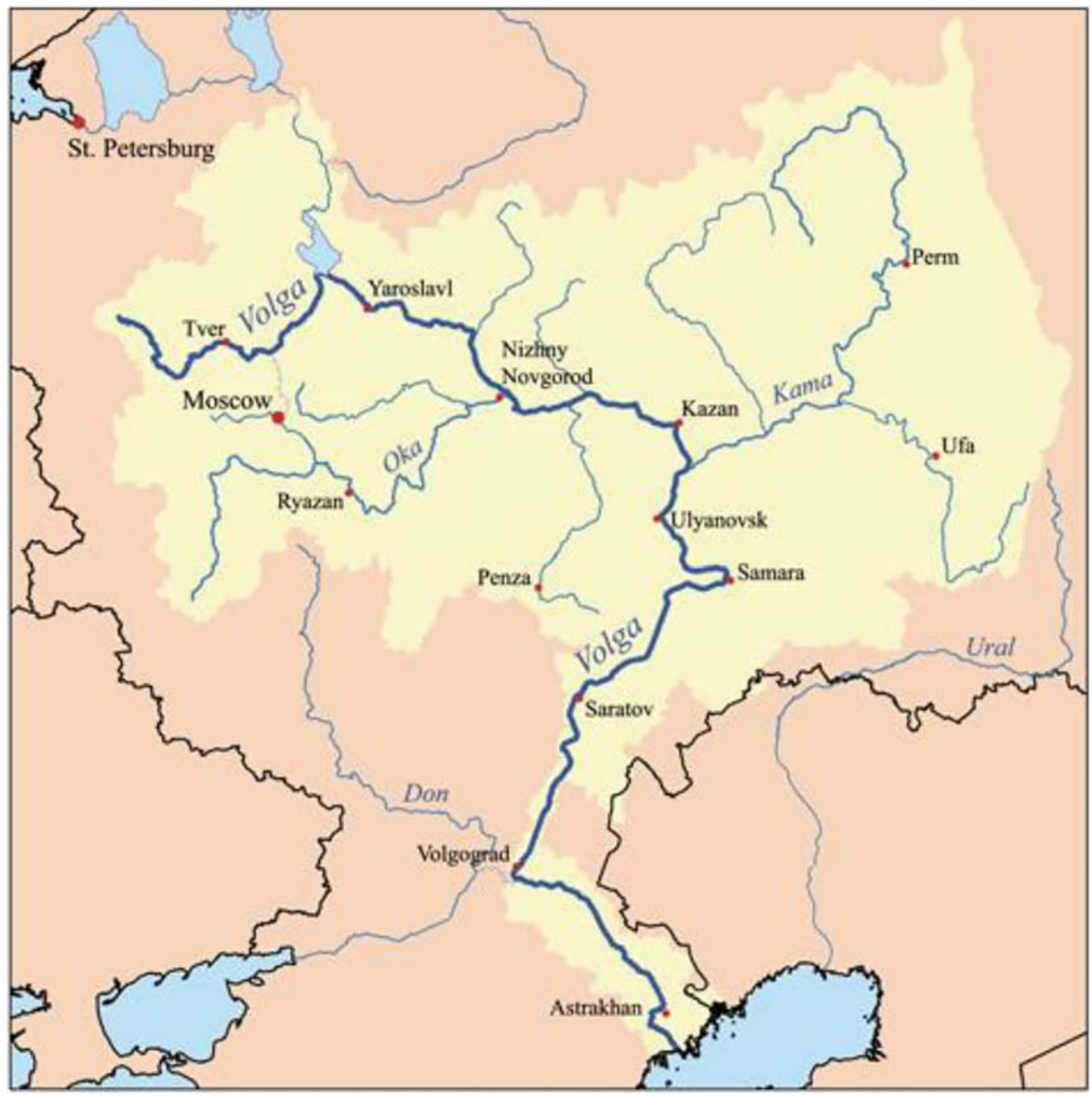

Fig. 1 The Volga River basin and some of the most important cities in it. Nearly half the Russian population live here

The Kuybyshev Reservoir on the Volga was built in 1954 and has a lake surface area of about $6350 \mathrm{~km}^{2}$, water volume of about $57.3 \mathrm{~km}^{3}$, average depth of about $10 \mathrm{~m}$, maximum depth of $41 \mathrm{~m}$, and elevation above sea level of $53 \mathrm{~m}$. The part of the river basin north of Kuybyshev is frozen from November to the middle of April. The Volga River contributes $43 \%$ of the flow to the Kuybyshev Reservoir. The Kama River contributes $38 \%$ and the Viatka River contributes $11 \%$ of the total water influx. The purpose with the Kuybyshev Reservoir was to secure minimum $4.5 \mathrm{~m}$ sailing depth along the whole river, to control and prevent flooding of cities and land and to generate a lot of electricity for the development of heavy industry in the Soviet Union.
It managed to do all of that fairly successfully. The largest tributary to the Volga River is the Kama River which joins the Volga at the Kuybyshev Reservoir at present. A number of reservoirs for hydropower and agricultural irrigation were built on the Kama River during the 1950s as a part of the Volga-Kama Project, reaching all the way to the north of the city of Perm.

The Gorkiy Reservoir (close to the city of Nizhniy Novgorod) has a surface area of about $1520 \mathrm{~km}^{2}$ and an average depth of about $8 \mathrm{~m}$. It was finished in 1955 and took a year to fill. The purpose was to secure sailing depth of $4.5 \mathrm{~m}$, and to generate more electricity for further industrialization of the Soviet Union. Before the construction of the dams on the Volga River, the 
Kazanka River, and the Kama River, the rivers were prone to flood the cites on their banks, as was the Moskva River, where the city of Moskva (Figs. 1 and 2 ) is located. The Moskva River runs to the Oka River, and the Oka River runs to the Volga River (Fig. 1).

About $45 \%$ of Russia's industry production and 50\% of the agricultural production is located in the Volga River basin, and historically, much environmental pollution ended up in the Volga (Filtzer 2008; Gorelitz and Zemyanov 2017). The pollution input to Volga was varied in the model; it was domestic sewage from the cities (nitrogen, phosphorus, organic matter) and waste from industries (organic matter, acids, heavy metals, organic compounds, solvents, mineral oil, and fuels). Lately, with modern chemistry, pesticides and endocrine disruptors are representatives of new types of pollutants that are extremely bioactive, but occur at so low levels that they are difficult to analyze. Volga is home of many types of sturgeon, and $90 \%$ or all sturgeon caught in Russia is from Volga, and $90 \%$ or all Russian Beluga caviar comes from the Volga. The Volga River is prominent in Russian culture, and protecting the most central river in the Russian Nation is a national priority (Gorelits and Zemyanov 2017). In the south, the Volga River runs through hot and arid lands and is one of the most important sources for water for the agriculture in those regions.

In August 2017, the Russian Government adopted the program Conservation and Prevention of Pollution of the Volga River 2017-2025, based on the conclusions and recommendations of the comprehensive scientific research (Hydrology and Environmental Service of Russia, Gorelitz and Zemyanov 2017).

\section{Objectives and Scope}

The objective is to adapt the basic principles developed for the process-oriented model system for the Kaban Lake system in Kazan (The Kaban Lakes Integrated Assessment Model (KLIAM)) (Frolova et al. 2020a, b, c) for an integrated assessment model for investigating possible antibiotics pollution in the Volga River. The model should be able to handle short-term variations (within a year) and long-term aspects (100-200 years). Antibiotics pollution in waterways is a global problem, and in particular where big rivers pass through large population centers (Gilbert 2019; Boxall and Wilkinson 2019; Wilkinson and Boxall 2019; Boxall et al. 2012; Fair and Tor 2014; Jones et al. 2005). During the last two decades, antibiotics use has increased significantly towards Central European levels (van Boeckel et al. 2014. Finds in the Volga River system suggests that it may possibly be an issue in Russian freshwater systems adjacent to large cities (Moisenko 1994; Obukhova and Lartseva 2014; Gabdulhakova et al. 2016).

\section{Methods}

The methodology uses systems analysis for conceptualization, as the preparation for building a simulation model using the STELLA software. The main standard methods of systems analysis and system dynamics modelling are used (Albin 1997; Binder et al. 2003; Forrester 1971; Greenfield et al. 2018; Kim 1992; Meadows et al. 1974; Roberts et al. 1982; Senge 1990; Haraldsson and Sverdrup 2005; Haraldsson 2004; Sverdrup 2018). We analyze the system using stockand-flowcharts and causal loop diagrams. The learning loop is the adaptive learning procedure followed in our studies (Senge 1990; Senge et al. 2008). The entering of the code follows from the causal loop diagrams and flowcharts developed in the conceptualization stage. The mass balance expressed differential equations resulting from the flow charts and the causal loop diagrams will be numerically solved using the STELLA® modelling environment (Senge 1990, Haraldsson and Sverdrup 2005, Sverdrup 2018).

The approach is that of engineering to making practical models (Chapra and Reckhow 1983; Chapra 1991). To the largest degree, all constants and settings have been based on observed system parameters, in order to reduce the need for calibration. A lot of the necessary input data from the system is missing. We have done a number of assumptions to reconstruct this from whatever information that is available in the literature, grey reports, or interviews with individuals.

The order of work was as follows:

- First build the hydrological basic model structure for the Volga River, simulating the river water flow and seasonal flow variations in the Volga

- Build and fill the major reservoirs Rybinsk (193545), Gorkiy (1953-1955), and Kyubyshev 19521956) on the Volga, in the hydrology model

- Build the antibiotics load module in the model 
Fig. 2 Moskva was flooded in 1907 and again in 1926 by the river Moskva, which runs to the river Oka, which runs to the river Volga (adapted after Gorelitz and Zemyanov 2017). Kremlin in the background, red square in front

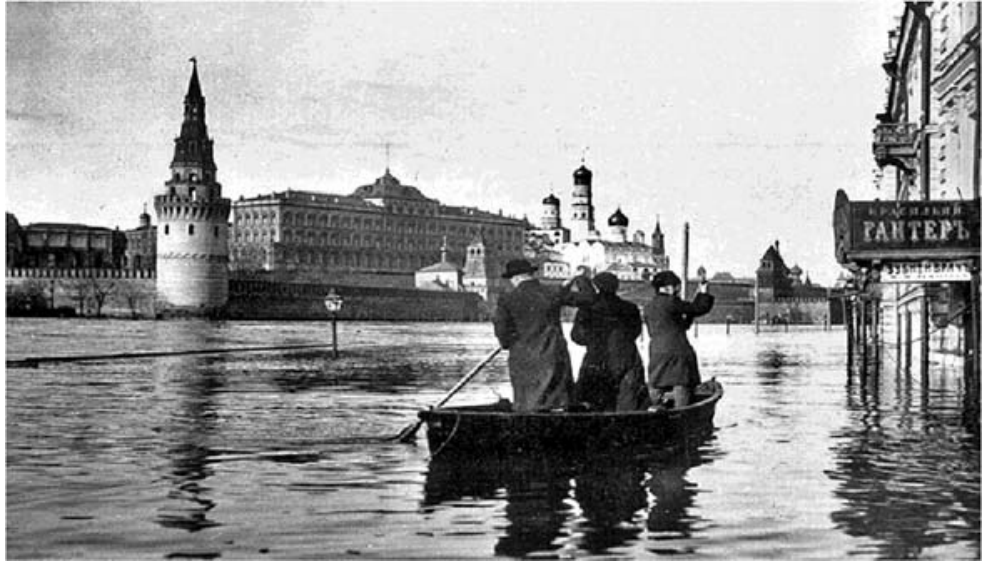

- Develop the antibiotics river pollution model for the water concentrations in the Volga river

- Develop the antibiotics soil transport and decomposition module to handle agricultural use of antibiotics

- Develop the microbial antibiotics resistance risk module in the model

All of this was done and completed.

\section{On Antibiotics}

\subsection{On Development, Production, and Use}

The discovery of penicillin in 1928 (Fleming 1929; Gaynes 2017) in Great Britain and sulfonamide (Domagk 1935) in 1932 in Germany changed the success of the treatment of bacterial infections dramatically (Tan and Tatsumura 2015). From 1928 to 1970, 270 new antibiotics were then developed (Fig. 3a). Recently, the rate has been falling off, and more substances are lost to microbial resistance than the number of new substances that are developed. An important key principle is that the substance used is specific for the microorganism, but harmless to human tissue or with limited toxicity to humans (Aherne et al. 1990; Andersson 2006; Gualerzi et al. 2013; Hurd et al. 2004; Leekha et al. 2011; Phillips et al. 2003; Shea 2003; Tan and Tatsumura 2015; Ventola 2011; Zaffiri et al. 2012).

The rate of development of new antibiotic substances has dropped since the end of the 1980s, and the number of effective antibiotics has dwindled significantly in the subsequent years (Fig. 3a). Thus, we have many antibiotic substances in use, but as the resistance fraction increases, the number of infectious cases that can be treated will dwindle. It was soon discovered that some microbes could become resistant to antibiotic substances designed to kill them (Aarestrup et al. 2001; Andersson 2006; Belkova et al. 2013; Heinemann et al. 2000; Obukhova and Lartseva 2014, 2018). In the last two decades, it has become evident that this would possibly 1 day become a problem, and at present, that situation has arrived.

In 2013, a total of about 131,000 metric tons of antibiotic substances were used worldwide in agriculture, while the total production of antibiotic substances was about 167,000 metric tons, leaving 66,000 t for human use (World Health Organization (WHO) 2015a, b, 2017). The implication is that $78 \%$ of all antibiotics produced in 2013 were used in agriculture, mostly for "growth promotion" (World Health Organization (WHO) 2015a, b, 2017). Antibiotic production is projected to reach $200,000-350,000$ t/year by 2030 (van Boeckel et al. 2015; van Boeckel 2018; Davies and Davies 2010; Allen et al. 2010; van Boeckel et al. 2014, 2015; Kirchelle 2018, 2019; Klein et al. 2017; World Health Organization (WHO) 2009, 2011, 2015a, b, 2017; van Bunnik and Woolhouse 2017). Figure 3b shows the global tonnage of antibiotics production and use; however, data on antibiotic usage and production is difficult to find, and its accuracy remains largely unknown.

\subsection{Pollution and Environmental Loads}

Typical concentrations found in other rivers are shown in Table 1 (Aherne et al. 1990; Castiglioni et al. 2006; Chee- 


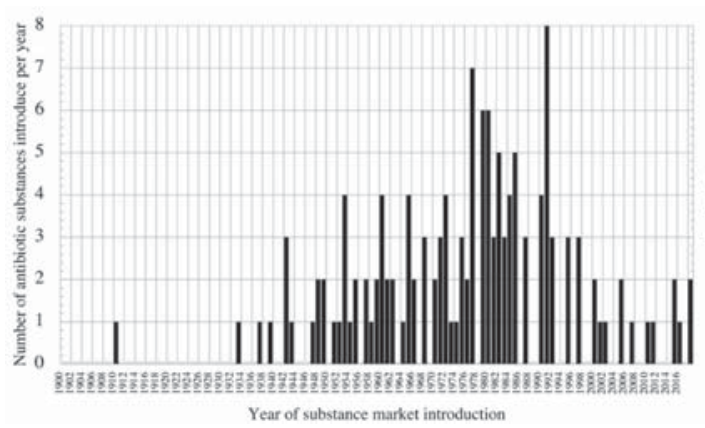

a)

Fig. 3 a The rate of discovery of new antibiotic substances are declining after 1980 (Sverdrup et al. 2020). Data from the World Health Organization (WHO), plot by Sverdrup et al. (2020). b The global tonnage of antibiotics substance production and predicted future production. Data extraction and graph by the authors from Davies and Davies (2010); Allen et al. (2010); van Boeckel et al. 2014, 2015; Klein et al. (2017); World Health Organization

Sanford et al. 2009; Ashton et al. 2004; Moisenko 1994; Paxéus 2004; Halling-Sørensen et al. 1998; Heberer et al. 1998; Grenni et al. 2018; Vishlenkova 2005; Chen et al. 2018). Similar values have been found elsewhere, and in some places, significantly higher values. Values up to 4 $10 \mu \mathrm{g} / \mathrm{l}$ in major rivers has been observed in developing countries and some European cities (Grenni et al. 2018; Vishlenkova 2005; Boxall and Wilkinson 2019; Wilkinson and Boxall 2019; Gilbert 2019).

The available data suggests that $80 \%$ of all antibiotics are used in food production (Fig. 3b). For rural animal husbandry on small-scale farms based on natural grazing, antibiotics in animal husbandry are not needed. Antibiotic need increases in the setting of animal crowding and industrial rearing practices in order to avoid infections under what in reality are unsustainable conditions for the animals. Antibiotics are also used to eliminate microbial competition for food substrates in pigs and chickens, so-called growth promotors. In terms of the risks for microbial antibiotics resistance, that is really a thoroughly unsustainable practice where greed has won over reason (Laxminarayan et al. 2013; Lyons 2014; Marshall and Levy 2011; de Kraker et al. 2016; Heilig et al. 2002). Meat from farms using antibiotics will contain residual antibiotics, which poses a potential risk for developing microbial antibiotic resistance (Center for Disease Dynamics, Economics, and Policy 2015; Ventola 2011; World Health Organization (WHO) 2015a, b, 2017; Interagency Coordination Group on antimicrobial resistance. 2019; Phillips et al. 2003; Price et al. 2015; Gaynes 2017; Heilig et al. 2002), as well as

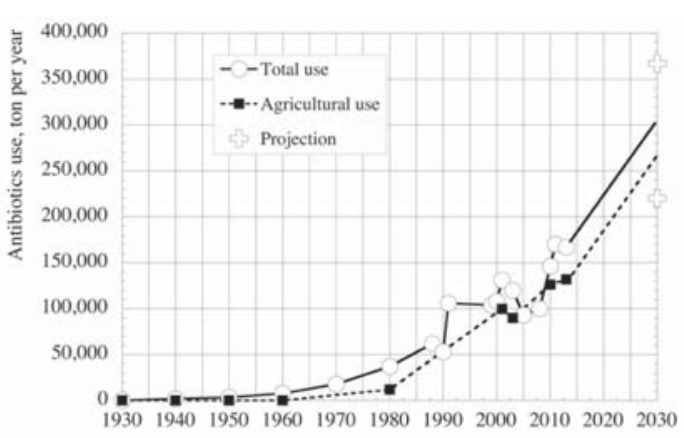

b)

(WHO) (2009, 2011, 2015a, b, 2017); Emerson de Lima Procopio et al. (2012); and Sarmah et al. (2006). The projections are from the WHO scenarios (2015a, b, 2017). Compiled by Sverdrup et al. (2020). One Chinese source claims that Chinese consumption alone was $162,000 \mathrm{t}$ /year in 2013 (Chen et al. 2018). In 2020, the global production, hence consumption, will be about 210,000 220,000 t/year

contaminate the final product. When mixed with several different antibiotics and growth hormones, the whole thing will care large risks for both consumers and the employed people at these plants (Cassini et al. 2019; Alder et al. 2006). We are no longer talking about what is normally called a farm (Economou and Gousia 2015; Kirchelle 2018, 2019; Lyons 2014; Phillips et al. 2003; Shea 2003; Silbergeld et al. 2008). There are many ways in which antibiotics end up in the environment and in waterways and drinking water:

1. Use of antibiotics in medical treatment of microbial infections. The residuals exit with excrements and urine, and enter the sewage. This happens in the home and in hospitals (ANSES 2011; Ashton et al. 2004)

2. Old medications are sometimes put in to garbage and find its way to landfills (Belkova et al. 2012; Moisenko 1994).

3. Medications get flushed down the toilet, ending up in the sewage, and are partly or not removed in the sewage treatment plants (Ashton et al. 2004; Castiglioni et al. 2006; Lyons 2014; Vieno et al. 2005; Woolhouse et al. 2015)

4. Antibiotics used in agriculture is 4-5 times larger weight than the medical use for humans. Especially with industrialized beef, poultry, and pork production, the use is large. More recently, it has been realized that industrialized salmon fish farming use large amounts of antibiotics in some countries (Aarestrup et al. 2001; van Boeckel et al. 2014, 2015; van Bunnik and Woolhouse 2017; Cogliani 
Table 1 Examples of antibiotics concentrations found in some rivers worldwide. The PNEC limit is $0.1 \mu \mathrm{g} / 1$

\begin{tabular}{llll}
\hline River & Country & Major city & Antibiotics concentration $(\mu \mathrm{g} / \mathrm{l})$ \\
\hline Tiber & Italy & Rome & $0.02-0.47$ \\
Po & Italy & Milano, Verona, Bergamo, Varese & $0.05-0.68$ \\
Lambro & Italy & Como, Monza & $0.36-0.61$ \\
Thames, & Great Britain & London, Bath & $0.05-0.23$ \\
Ganges & India & Delhi, Agra, Dacca & $0.30-35$ \\
Xunwu & China & Beijing & $0.19-0.83$ \\
\hline
\end{tabular}

et al. 2011; Economou and Gousia 2015; Gilchrist et al. 2006; Heilig et al. 2002; Laxminarayan et al. 2013; Marshall and Levy 2011; Zurek and Ghosh 2014; Higuera-Llantén et al. 2018). The antibiotics used in fish farming end up in the sediments and ultimately pollute the oceans. The antibiotics used on land end up in the manure and can run off to waterways and groundwater. Part of it will contaminate the meat produced, and enter the human food chain (Landers et al. 2012; Penesyan et al. 2015; Phillips et al. 2003; Podolsky 2018; Shea 2003; Wegener 2003, WHO 2011).

The development of antibiotics resistance is a very serious problem for modern health care, the threat is near and very substantial in terms of potential loss of life (Belkova et al. 2013; Cassini et al. 2019; Davies and Davies 2010; de Kraker et al. 2016; Ling et al. 2015). Not very much is known about the long-term exposure to low dosages and what effect that has on both humans, animals or bacteria, but enough to argue for great caution. It needs to be kept in mind that these substances and their metabolites may also have endocrine disrupting effects, and these may occur at very low dosages.

\subsection{Analyzing the Antibiotics Pollution Situation}

\subsubsection{General Overview}

Figure 4 shows the pathways for antibiotic substances in human medical use and in agricultural commercial use. There is leakage from the human use to the natural environment through the waste disposal system (or lack of it). It is to be remembered that more than half of all raw sewage is never ever treated in any way. From agricultural use, antibiotics leaks to rivers, lakes, soils, and oceans in a very pervasive way, there is almost no treatment of effluents ever anywhere. The agricultural use is 4 times larger than all human uses. It is evident from the flowchart that a lot of flows with antibiotics never come to any post-use treatment. The use of antibiotics in society is driven by three reinforcing loops. These have been shown in the causal loop diagram developed for the problem, displayed in Fig. 5. The original loop based on successful treatment is marked with R1. The efficient treatment of infections caused great increase in quality of living and spurred more use to create more successful cures. However, it was soon found out that use of antibiotics would increase fodder yield and production rates in animal production. This led to higher profits, which has been a strong drive for more antibiotics use in meat production (R3). This has led to political lobbying to reduce legislation that would limit the use. Finally, the resistance problem is made substantially worse by antibiotics pollution in addition to massive use on animals, forming many balancing loops in the system. The standard type of waste water treatment is not very effective in reducing antibiotics in sewage water. Once specialized wastewater treatment is introduced, a last reinforcing loop is created (R4). Less success in treatments due to resistance to antibiotics leads to lobbying for more regulations. The flowchart for stock of effective antibiotics lost antibiotics to resistance and a part that possibly can be salvaged by keeping them in resting for 100 years (Sverdrup et al. 2020) is shown in Fig. 5.

\subsubsection{Estimating Human Society Input, Load to the Environment, and the Load to the Volga River}

The total intake of antibiotic substances in the Volga River basin was not available to us. For Russia, in 


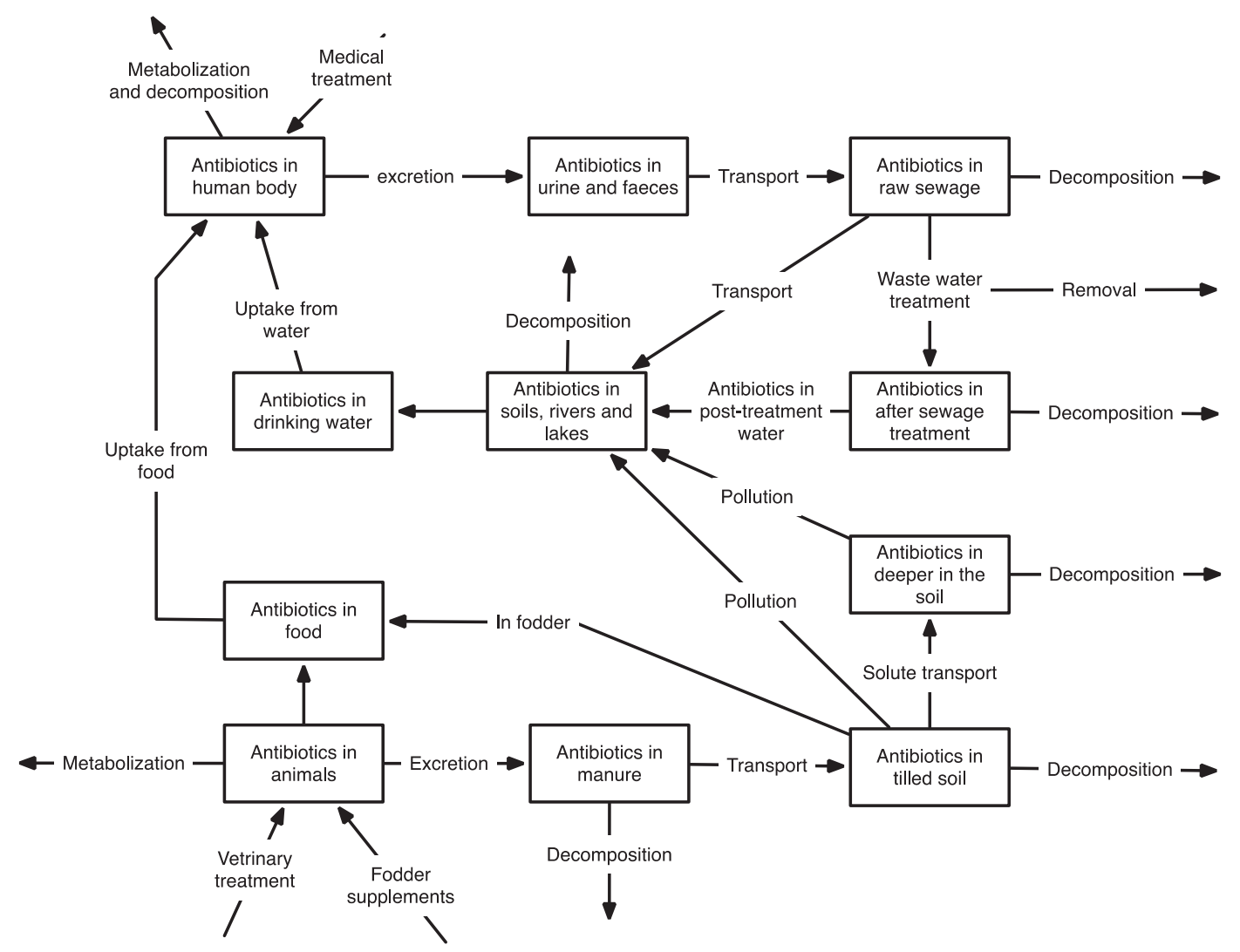

Fig. 4 Flowchart for antibiotics in the system. This was used in the design of the antibiotics module

general, it was available. Ratchina et al. (2009); Ratchina (2015) reports outpatient defined daily dose (DDD) of 12.5 DDD per person per year and an hospital use of 1.85 DDD per person per year; this is supported by the studies of Fokin et al. (2011a, b); Belkova et al. (2013); Wegener 2012; and ESAC Yearbook (2009). She reports over the use over the years 2003-2015, and the upward trend has flattened off and is at about a total DDD in the range of 12-15 doses per person per year. We have made approximate estimates for the antibiotics input, based on this best available information. We have used two methods of estimation:

1. For the year 2001-2015 use, the DDD average value for Russia from the literature and scale down to the Volga River basin.

2. To use the total global consumption and scale down to use in the Volga River basin, using population. This assumes the Russian use to be at the global average which fits with Ratchina (2015) and Fokin et al. (2011a, b).
The First Approach Use the 2015 DDD values for Russia from the WHO (2011) and scale up: the medical input to the population in the Volga River basin in our first approximation was done using the expression:

Input to the population $=\mathrm{DDD} \times \mathrm{P} \times \mathrm{S}$

DDD is the defined daily dose per inhabitant, $\mathrm{P}$ is the population in the catchment (65 million people), and $\mathrm{S}$ is dosage strength.

$\mathrm{S}$ varies a lot between the different substances, and that we have set at $\mathrm{S}=0.5 \mathrm{~g}$ (73.6 billion standard units is corresponding to about $35,000 \mathrm{t}$ of antibiotics substance according to Hutchinson et al. (2004); WHO (2011); van Boeckel et al. (2014); Center for Disease Dynamics, Economics, and Policy (2015); and Pikkemaat et al. (2016). Thus, each unit has the weight of $0.476 \mathrm{~g}$ per unit in 2010. An issue is that DDD varies between antibiotics, and thus, it is not uniquely defined how heavy each DDD is when it is added up (Hutchinson et al. 2004 reports depending on substance from $0.5-2 \mathrm{~g}$ per DDD to a maximum of $14 \mathrm{~g}$ per DDD, with an average of about $1 \mathrm{~g}$ per DDD). Filling in the numbers for the Volga River basin, we get $488 \mathrm{t}$ of antibiotic 


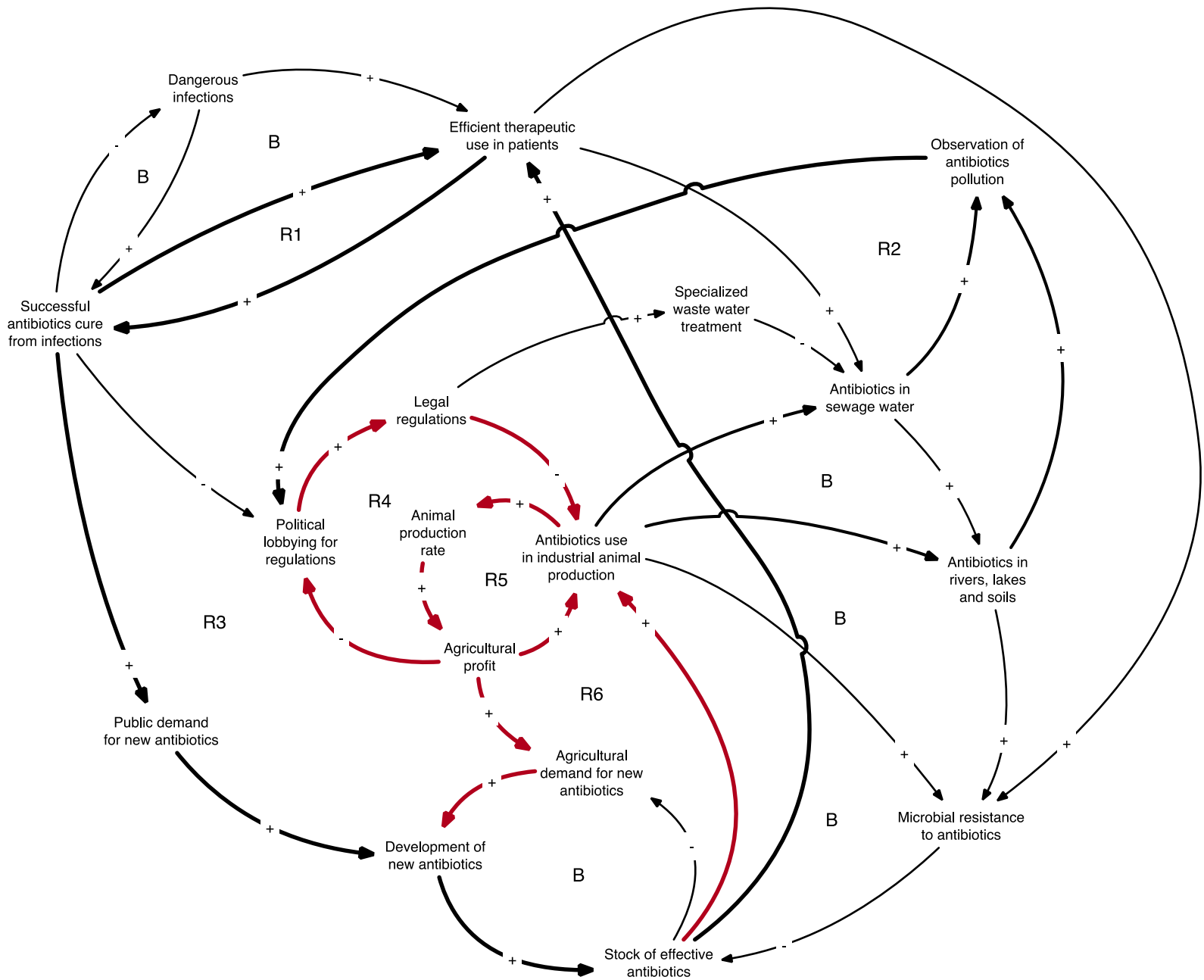

Fig. 5 A causal loop diagram for the problem of antibiotics use and development of microbial resistance as discussed in the text. Such diagrams are important for investigating the possible policies to mitigate the different aspects of the antibiotics problem

substances per year in medical use. DDD comes from WHO (2011) numbers above in Fig. 6. We can add about 20 t/year taken without prescription, at home, off the record (Ratchina 2015), and this then amounts to a total amount of about $508 \mathrm{t} /$ year in the Volga River basin. This is consistent with what we are using as the modelling input (Fig. 7). The agricultural use to the Volga River basin is needed. It is related to the number on cattle, pigs, and poultry in intensive industrial production (cattle feed lots, pig houses, poultry houses):

Input to agriculture $=$ Input to swine + input to cattle

$$
+ \text { input to poultry }
$$

In the Volga region, we have $50 \%$ of all Russian agricultural production (Gorelits and Zemyanov 2017). This implies:

- $\mathrm{n}_{\text {Swine }}$ : The number of swine has declined from 45 million head in 1988 to 24 million pigs in 2015, resulting in 15 million tons slaughter weight per year, $35 \%$ of the meat weight produced (Houghton 2018). This has later slightly increased to about 28 million swine (Index Mundi 2019; USDA Foreign Agricultural Service 2017; Flanders Investment and Trade 2018).

- $\mathrm{n}_{\text {Cow }}$ : The number of dairy cows were was 17 million in 1988, and there were 7 million cows in 2019. Beef is $7 \%$ of the meat production (Index Mundi 2019). Total cattle inventory was 19 million head in 


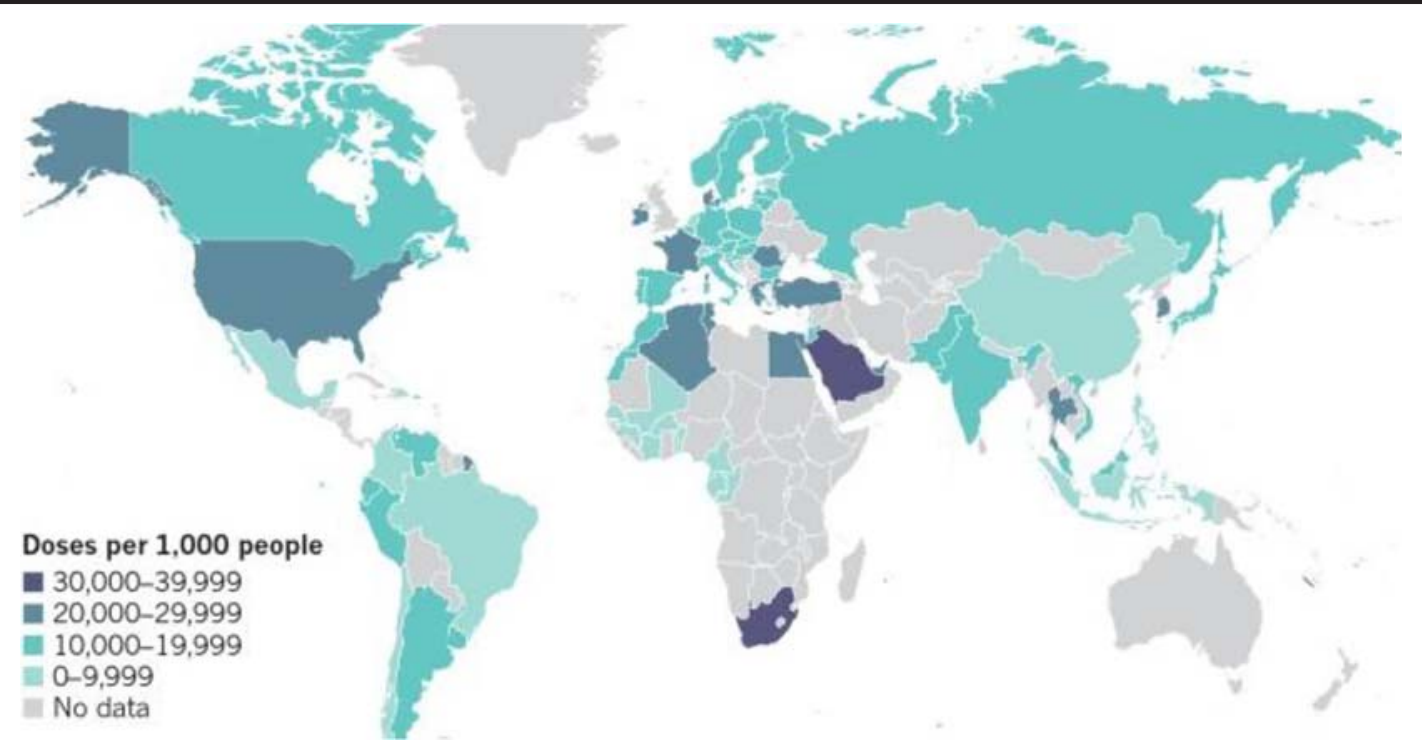

Fig. 6 Dosages used for medical treatment in the world (WHO 2011). We have assumed that the value for Russia is 15,000 per 1000 people

Fig. 7 Estimated total antibiotics inputs to the Volga River population and agricultural animal stocks, before it has reached the Volga for business-asusual (a) and two policy scenarios (b, c). a Policy 1: do nothing, this is business-as-usual after 2020. b Policy 2: ban all agricultural use during the time period 2020 2030. c Policy 3: phase out agricultural use during 2020-2030, and clean all sewage to $90 \%$ for antibiotics during 2020 to 2030 a): Policy 1; Do nothing, this is Business-as-usual after 2020 .

b):

Policy 2: Ban all agricultural use during the time period 2020-2030

c):

Policy 3: Phase out agricultural use during 2020-2030 and clean all sewage to $90 \%$ for antibiotics during 2020 to 2030 .
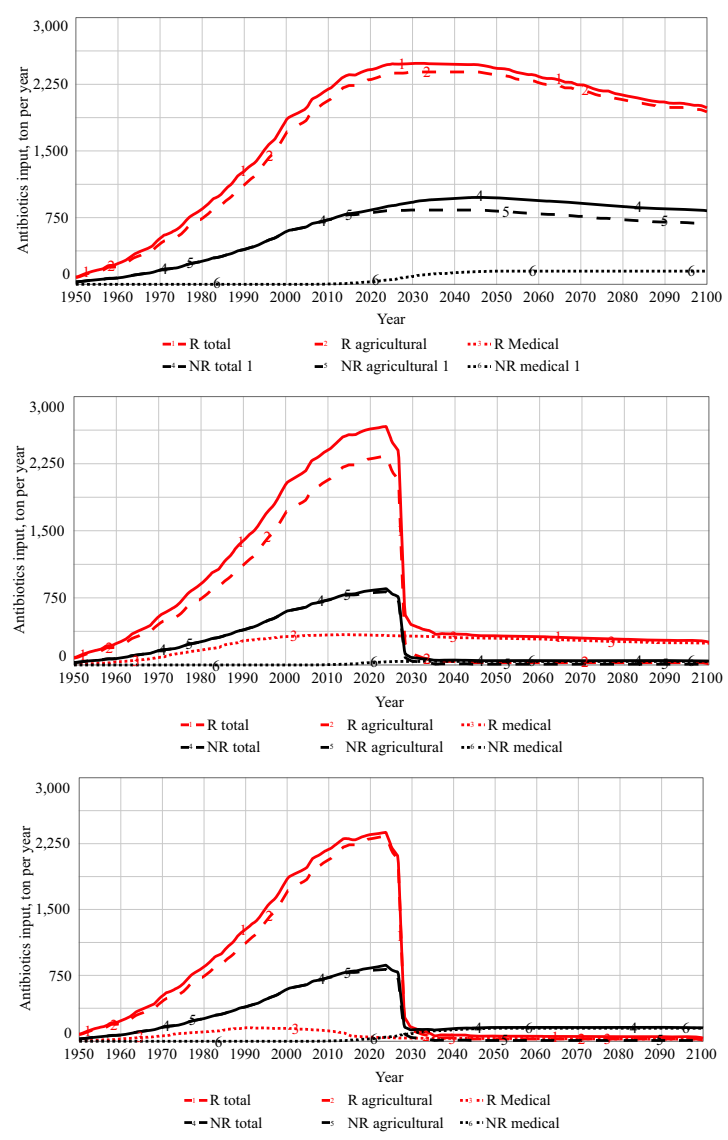
Table 2 Estimation of animal contribution to the Volga River basin input in tons per year. The swine metabolize antibiotics just like humans. Cattle a bit more as they are ruminants and the food stays longer in the intestines. Poultry has a fast digestion system and digest antibiotics less than the others. Data from I

\begin{tabular}{|c|c|c|c|c|c|c|c|c|c|}
\hline Animal & $\begin{array}{l}\text { DDD per person per } \\
\text { year }\end{array}$ & $\begin{array}{l}n \\
\text { million }\end{array}$ & $\begin{array}{l}w \text { weight adjustment versus a } \\
\text { person }\end{array}$ & $\begin{array}{l}\text { Juvenile } \\
\text { included }\end{array}$ & $s$ & $\begin{array}{l}1- \\
X_{M}\end{array}$ & $f$ & $X_{A}$ & $\begin{array}{l}\text { Input estimate } \\
\text { (t/year) }\end{array}$ \\
\hline Swine & 15 & 28 & 1 & $2 / 3$ & 22 & 0.35 & 0.5 & 0.87 & 937 \\
\hline Cattle & 15 & 19 & 5 & $2 / 3$ & 22 & 0.25 & 0.5 & 0.40 & 1044 \\
\hline Poultry & 15 & 200 & 0.014 & $1 / 2$ & 22 & 0.50 & 0.5 & 0.90 & 104 \\
\hline Sum & & & & & & & & & 2085 \\
\hline
\end{tabular}

2017 (USDA Foreign Agricultural Service 2017; Flanders Investment and Trade 2018).

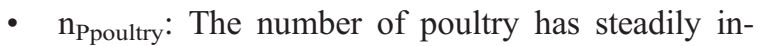
creased from 30 million in 1999 to 200 million poultry in 2019 , which was $58 \%$ of the meat production (Index Mundi 2019; USDA Foreign Agricultural Service 2017; Flanders Investment and Trade 2018).

To make the input estimate, we scale up from a treatment of 14 days per cure to continuously, a factor of 22. We have used the $\mathrm{Di}$ as with the value of the human DDD, but scaled to animal live weight. We assume a pig to be $70 \mathrm{~kg}$, a normal cow to be $350 \mathrm{~kg}$, and a chicken to be about $1 \mathrm{~kg}$ live weight. But many of these are youngsters, this we reduce the weight with $2 / 3$ for swine and cattle and with $1 / 2$ for poultry (Table 1). We get the Eq. (3):

$$
\begin{aligned}
\text { Load }= & \sum_{i=1}^{\text {animals }} D_{i} \times n_{\text {animal }, i} \times w_{i} \times s_{i}\left(1-X_{M, i}\right) \\
& \times f \times J_{i} \times X_{A, i}
\end{aligned}
$$

where $D_{i}$ is the dose per animal, $n_{i}$ is the number of animals in million of the particular animal $i, w$ is scaling the weight to that of a human (swine $=1$, cow $=5$, chicken $=0.014), s$ is the scaling from a human medical cure of 14 days to almost continuous feeding $(s=22)$, with a 1 month pause before slaughter, $X_{M}$ is the fraction not metabolized (for a swine 0.35 ), and $X_{A}$ is the fraction of the production done in feedlots and industrial plants (cattle 0.5 , swine 0.9 , poultry 0.9 ). $f_{i}$ is a scaling factor from the medical DDD to what is used in animals, and $J_{i}$ is scaling for the difference in weight by including juveniles. We have assumed that only swine, cattle and poultry are treated, all others are not (sheep, goat, turkey, duck, rabbit, horse, goose). By filling in the numbers, we get Table 1 (data from Index Mundi 2019; USDA Foreign Agricultural Service 2017; Flanders Investment and Trade 2018; Gorelits and Zemyanov 2017) (Table 2).

Alternatively, we can scale up from medical use to the total use by a simple scaling. We use the general stated factor the agricultural use is 4 times the medical use (Fig. 1b). This would yield $508 \times 4=2032$ t/year, this compares well with $2085 \mathrm{t} / \mathrm{year}$ in Table 1 . The Volga River has received high dosages of organic waste and bacteria from the meat trade, thus exposing a lot of

Table 3 Overview of estimates of population inputs to the population of the Volga River basin, focusing on medical use. Despite the difference in methods, the estimates appear as consistent

\begin{tabular}{lllll}
\hline Estimation method & \multicolumn{2}{l}{ Antibiotics substance (t/year) } & Agricultural use & Total use \\
\cline { 2 - 5 } & Medical use & Human unrecorded & 2032 & 2540 \\
First approach & 487 & 20 & 2085 & 2592 \\
& & & 1680 & 2100 \\
Second approach & 400 & 20 & 1932 & 2406 \\
Average & 454 & 20 & & \\
\hline
\end{tabular}


Table 4 Some data on the Volga catchment in terms of water flow rate and population of major cities in the river basin

\begin{tabular}{|c|c|c|c|c|}
\hline River & City node & Flow rate at Volga $\left(\mathrm{m}^{3} / \mathrm{s}\right)$ & Flow rate at Volga (million $\mathrm{m}^{3} /$ year) & City population \\
\hline Tvertsa & Tver & 55 & 1734 & 410,000 \\
\hline Vetluga & Yaroslavl & 255 & 8042 & - \\
\hline Kostroma & Yaroslavl & 85 & 2680 & \\
\hline Mologa & Rybinsk & 300 & 9462 & - \\
\hline Sheksna & Rybinsk & 172 & 5424 & - \\
\hline Kazanka & Kazan & 300 & 9462 & $1,800,000$ \\
\hline Sviaga & Sviyashk & 2590 & 81,688 & 20,000 \\
\hline Kama & Uljanovsk & 4100 & 129,300 & 640,000 \\
\hline Samara & Samara & 50 & 1577 & - \\
\hline Moskva-Oka & Moskva/Nizhniy Novgorod & 1260 & 39,740 & $18,000,000$ \\
\hline Oka & Ryazan & & & 530,000 \\
\hline Sura & Penza & 260 & 8100 & 550,000 \\
\hline Kama & Perm & & & $1,100,000$ \\
\hline Ufa & Ufa & 388 & 12,240 & $1,100,000$ \\
\hline Volga & Rybinsk outlet & 600 & 15,510 & - \\
\hline Volga & Yaroslavl & & 41,000 & 610,000 \\
\hline Volga & Nizhniy Novgorod & & 72,400 & $1,250,000$ \\
\hline Volga & Samara & & 165,000 & $1,200,000$ \\
\hline Volga & Saratov & & 183,000 & 900,000 \\
\hline Volga & Volgograd & & 190,000 & 1000,000 \\
\hline Volga & Astrakhan & 8060 & 254,200 & 530,000 \\
\hline Sum & & & & $29,670,000$ \\
\hline
\end{tabular}

bacteria to antibiotics once they start to occur (Dunaev 1833; Krestovnikov 1870; Kalimullin 2005; Kalimullin and Vinogradov 2015). Before the output from the population reaches the river, they pass the sewer system and hopefully also a functioning sewage treatment plant, where some of the antibiotics disappear (Table 3).

The Second Approach Use global consumption and scale it down to average global use in the Volga River basin. In 2015, the total global antibiotics consumption was 180,000 t/year. The global population in 2015 was 7 billion people. The population of the Volga region was about 65 million people in 2015. Thus, the antibiotics consumption in the Volga region would have been in the order of 220,000 t/year times the 143 million people in Russia, divided by 7000 million people in the world, scaling to the Volga River basin which has $50 \%$ of the Russian agriculture, gives about $2100 \mathrm{t} /$ year. Assuming that $80 \%$ of this would be agricultural use, we would get the human use is $420 \mathrm{t} / \mathrm{year}$. The antibiotics pollution load in the Volga River basin is regionally distributed in the model, the medical input according to

Table 5 Some data on the major reservoirs in the Volga catchment. 1-From Volga, 2-total inflow

\begin{tabular}{llllllll}
\hline Reservoir & $\begin{array}{l}\text { Water volume } \\
\left(\mathrm{km}^{3}\right)\end{array}$ & $\begin{array}{l}\text { Surface area } \\
\left(\mathrm{km}^{2}\right)\end{array}$ & $\begin{array}{l}\text { Average depth } \\
(\mathrm{m})\end{array}$ & $\begin{array}{l}\text { Max depth } \\
(\mathrm{m})\end{array}$ & $\begin{array}{l}\text { Build } \\
\text { year }\end{array}$ & $\begin{array}{l}\text { Flow rate }\left(\mathrm{m}^{3} /\right. \\
\mathrm{s})\end{array}$ & $\begin{array}{l}\text { Residence time } \\
(\text { years })\end{array}$ \\
\hline Rybinsk & 24.4 & 4560 & 5.6 & 16 & 1941 & 600 & 0.50 \\
Gorkiy & 12.2 & 1520 & 8.0 & 24 & 1955 & 1860 & 0.15 \\
Kuybyshev & 57.3 & 6350 & 9.8 & 41 & 1954 & 7100 & 0.24 \\
\hline
\end{tabular}




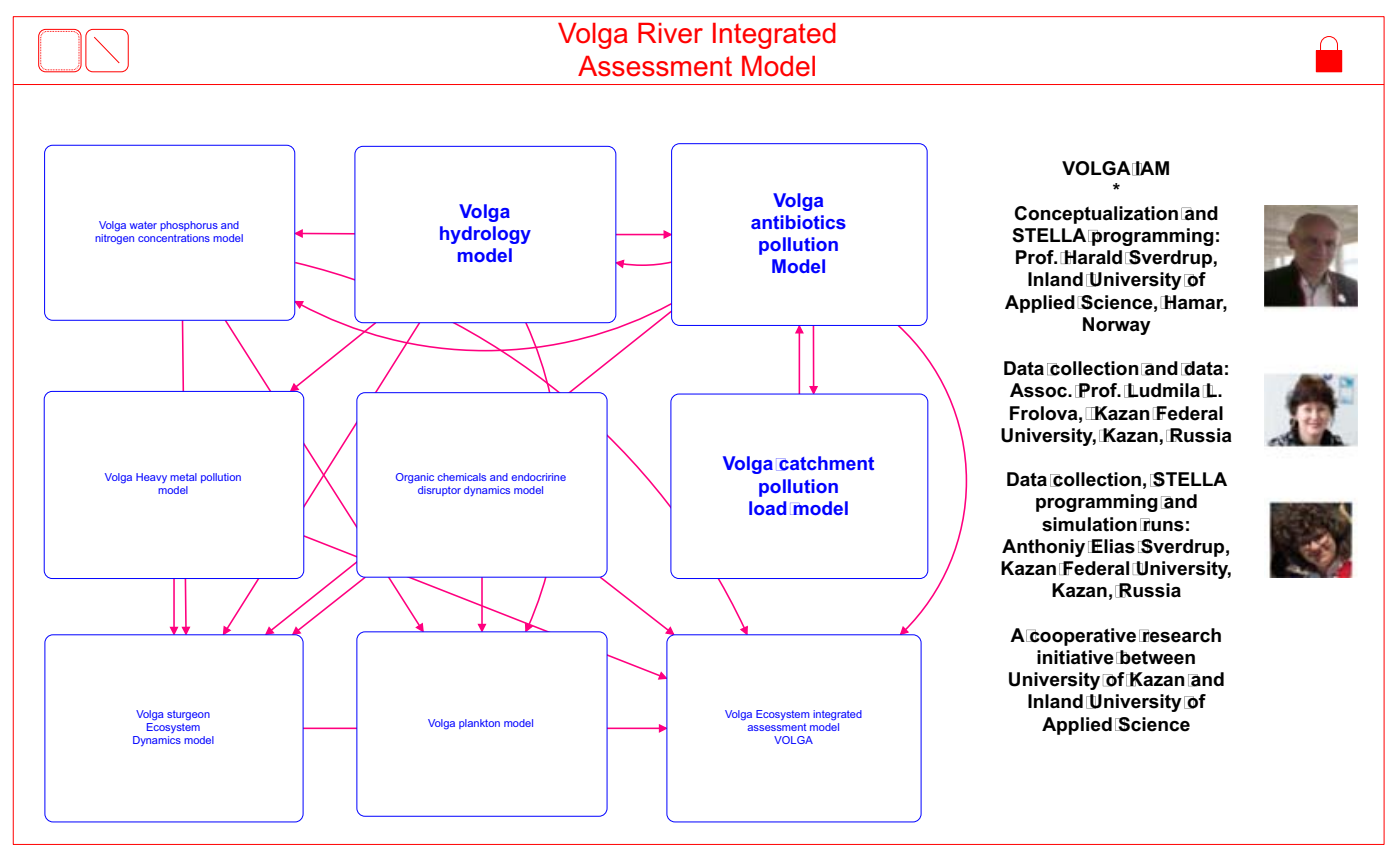

Fig. 8 Overview of the integrated assessment model for Volga

population density, and to the river passing through those areas. A part of the antibiotics will decompose in the river on the way and in the large reservoirs. The agricultural load is distributed proportionally to the total livestock density in the Volga River basin (poultry, pigs, cows in feedlots, but not in extensive grazing). The human input comes after human metabolization and decomposition in the sewage system, and the agricultural input comes after animal digestion and decomposition in soils and runoff. A very significant part of the agricultural antibiotics inputs (80-90\%) will disappear on the way to the Volga River, having been decomposed on the way (production of sheep, goat, turkey, horse, duck, and rabbit are kept outside the calculation). We may summarize the results from approximations as shown in Table 1. A rough estimate of how much reaches the Volga River, see Tables 2, 4, and 5.

\subsection{Policy Options}

Figure 7a shows the estimated total antibiotics inputs to the Volga River population and agricultural animal stocks, before it has reached the Volga for business-asusual (Fig. 7a) and two policy scenarios (Fg. 7b and c). The policies investigated are as follows:
1. Do nothing; this is business-as-usual after 2020 . Ban all agricultural use during the time period 2020-2030. The use is phased out completely during the 10 years from 2020 to 2030 .

2. Ban all agricultural use during the time period 2020-2030.

3. Ban all agricultural use during the time period 2020-2030, and clean all sewage to $90 \%$ for antibiotics during the time period 2020 to 2030 .

Everything before 2020 is the same in all policy scenarios. The agricultural use of antibiotics is phased out completely during the 10 years from 2020 to 2030 under policies 2 and 3 . The sewage is modified to gradually eliminate $90 \%$ of the antibiotics in the sewage during the 10 years from 2020 to 2030 under policy 3 .

\section{Model Description}

\subsection{Overview}

The model has been developed and programmed in the STELLA Architect software. Figure 6 shows an overview of the main deck in the VOLGA model system. Some data for the components in the system is shown in 
Table 1. The simulation model has 3 main parts at present; they can be seen in Fig. 10:

1. The hydrological module for the river and the reservoirs

2. Antibiotics module calculating antibiotic solute transport and attenuation caused by decomposition along the route in the soils, sewage, river, and the reservoirs

3. The pollution input module, generating input from medical use and agricultural use

Inside each box in the diagram, a submodel is situated. The boxes with small script in Fig. 6 are under development and not yet operational. The boxes with small text are modules under (Fig. 8) development.

\subsection{Hydrology Module}

The hydrological model in the STELLA Architect software window is shown in Fig. 9 (Frolova et al. 2020b). The module has an internal hydrological structure based on water mass balance along the river channel. Rain is assumed to become either evapotranspiration or runoff, but there is no net change in ground water amounts. Water accumulates in the reservoirs, where the output depends on gate settings, hydropower production, and water level in the reservoirs. Water leaves with outflow, through turbines and evaporation from the big reservoirs. Water enters the Volga River and the reservoirs by stream inflow and large tributary rivers. The variations in level in the reservoirs are simulated by the model.

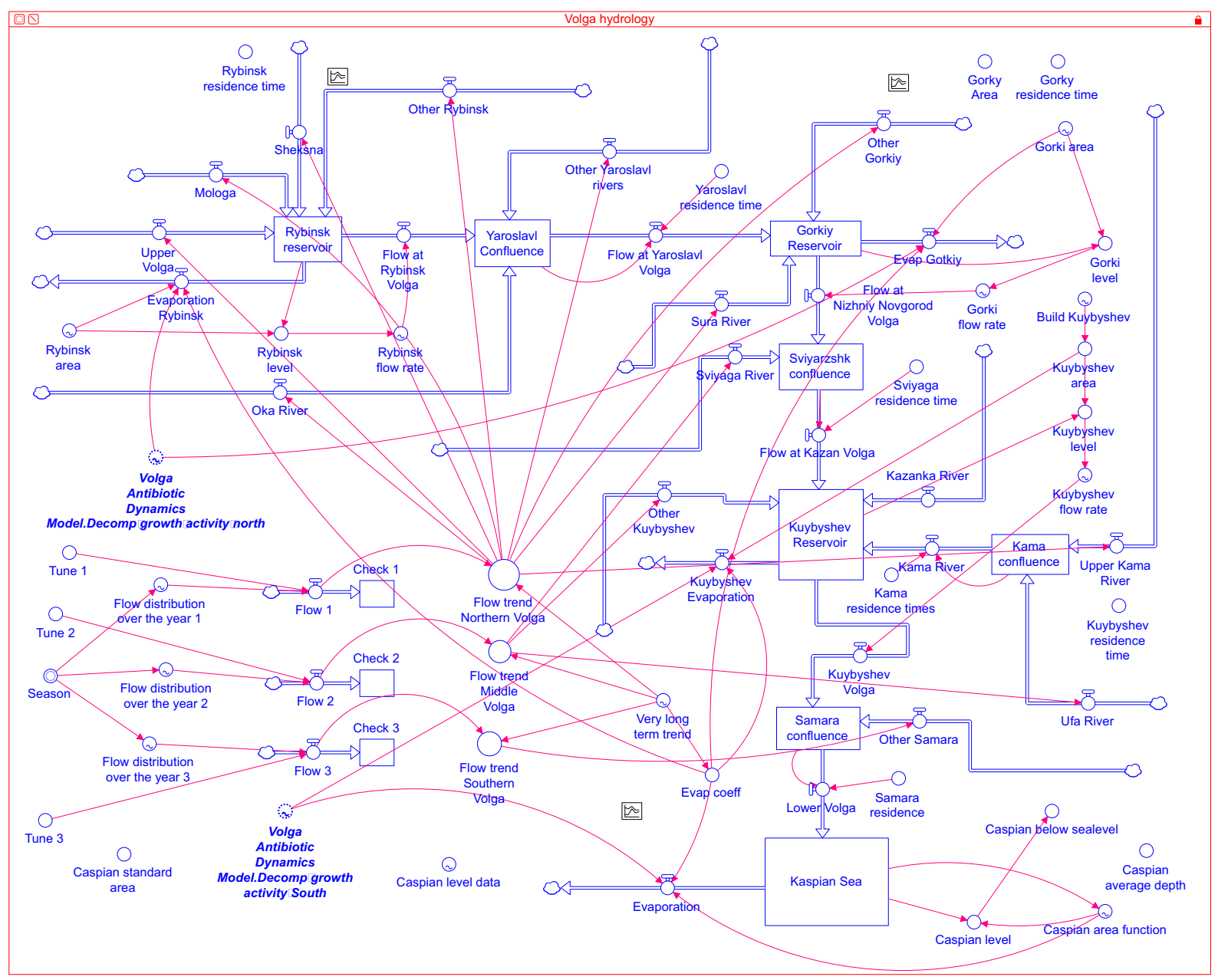

Fig. 9 The hydrological module in the Volga model in the STELLA Architect software window 


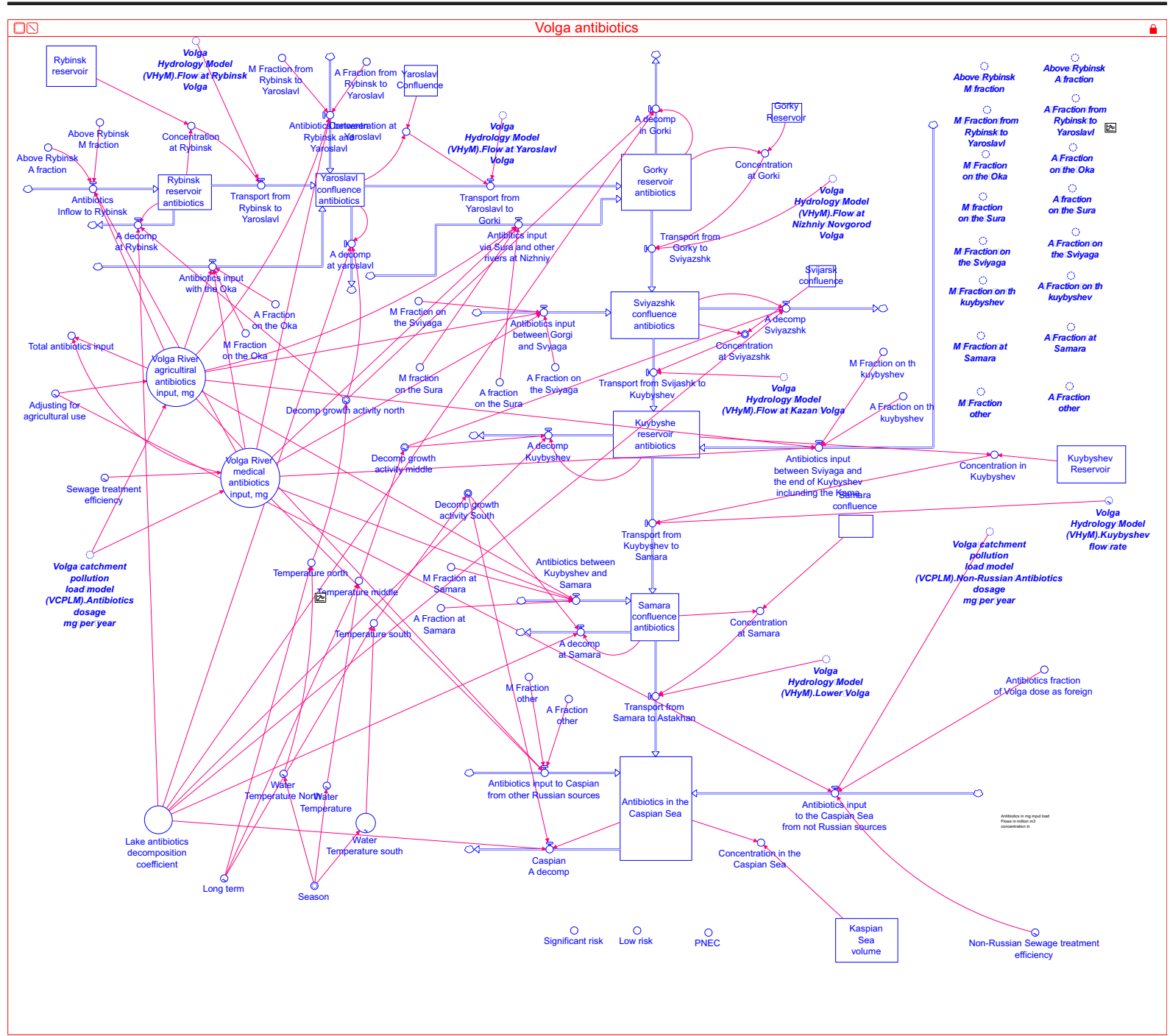

Fig. 10 The antibiotics module in the Volga model in the STELLA Architect software window

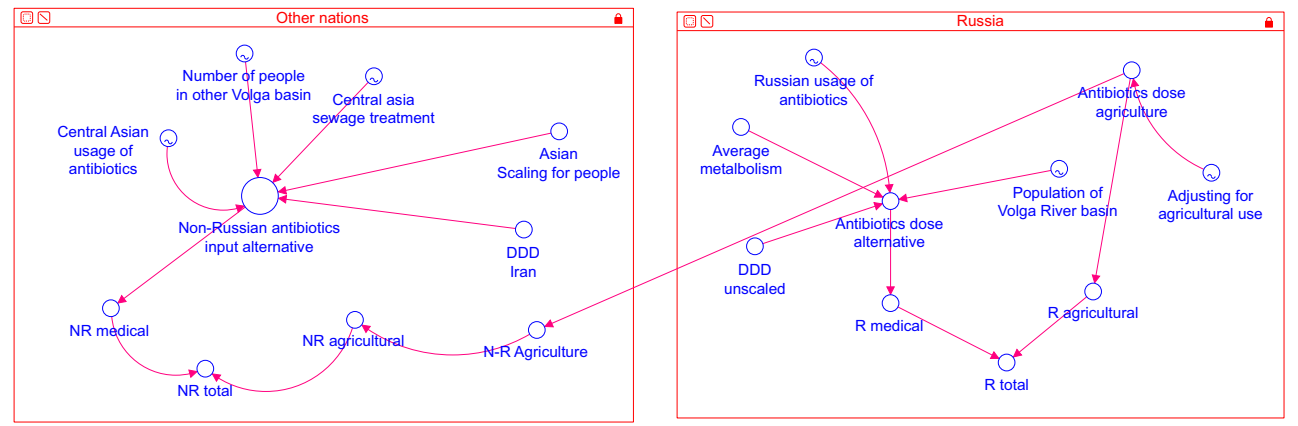

Fig. 11 The antibiotics pollution module in the Volga model in the STELLA Architect software window 

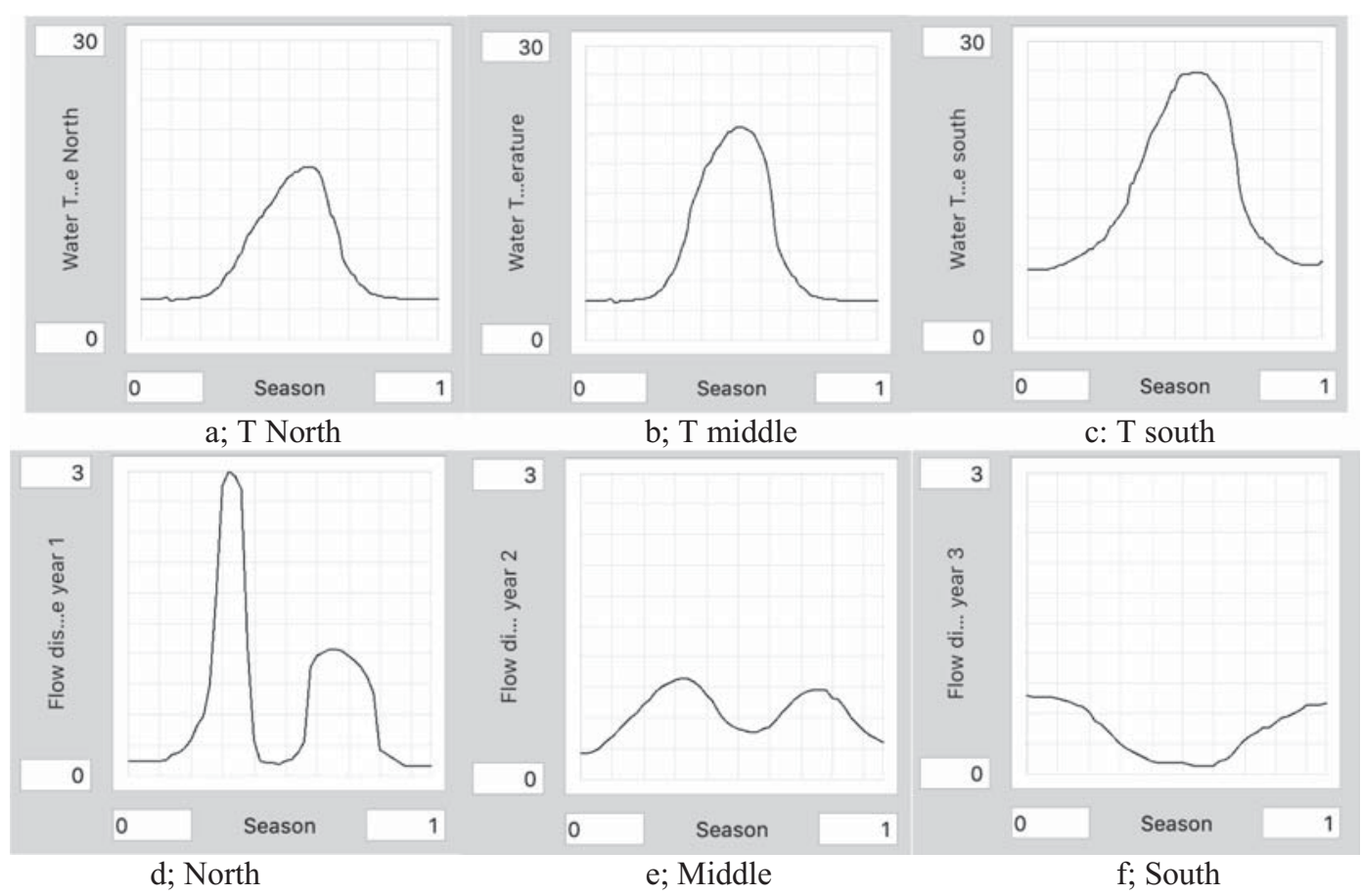

Fig. 12 Forcing functions used in the model. Annual temperature regime on the a northern, $\mathbf{b}$ middle, and $\mathbf{c}$ southern parts of Volga. Annual flow variations in the $\mathbf{d}$ northern, $\mathbf{e}$ middle, and $\mathbf{f}$ southern parts of Volga

\subsection{Antibiotics Module}

The antibiotics module is shown in Fig. 10. The applied mass balance in the model for antibiotic substances is (Frolova et al. 2020c):

Inflow + sediment desorption $=$ accumulation + decomposition + sediment adsorption

$$
+ \text { outflow }+ \text { sedimentation }
$$

Inflow is water inflow times the concentration in it, and accumulation is the increase in the lake water stock. Sorption is adsorption to organic matter in the sediments, decomposition is microbial decomposition in the water by microorganisms, and desorption is when the organic matter in the sediments release adsorbed antibiotics to the water body. Sedimentation is when antibiotics follow dead plankton to the bottom. Some of the antibiotics will desorb to organic matter and slowly release again back into the water. Some will be buried in the sediments (Fig. 11). The rate of decomposition of antibiotics is given by the equation (Chapra and Reckhow 1983; Frolova et al. 2020c):

$$
\mathrm{r}=\mathrm{k}_{\text {Decomposition }} *[\text { antibiotics }] * \mathrm{~V} * \mathrm{f}(\mathrm{T})
$$

$\mathrm{k}_{\text {Decomposition }}$ is the decomposition rate coefficient, [antibiotics] is the concentration of antibiotics in the water, $\mathrm{V}$ is the water volume where decomposition takes place and $f(T)$ is the function accounting for rate change when the temperature changes.

Figure 12 shows the forcing functions used in the hydrology part of the model in the diagrams marked a, $\mathrm{b}$, and $\mathrm{c}$. The annual temperature regime is shown in the row below. The figure shows some of the scaling functions used in the model. The regions are as follows the (a, d) upper, (b) middle and (c, f) southern Volga, (a, d) northern part, $(b, e)$ the middle part (Climate date.org 2020). The annual temperature regime was used as input to the decomposition rate for antibiotics in the river and to drive evaporation from the large reservoirs. Figure $12 \mathrm{~d}-\mathrm{f}$ show the annual flow variations in the northern, middle, and southern parts of the Volga River basin.

The antibiotics loads to the lakes are not known and have never been measured. We have used a suggestion for an antibiotics consumption load and subsequent pollution load, based on the fact that 


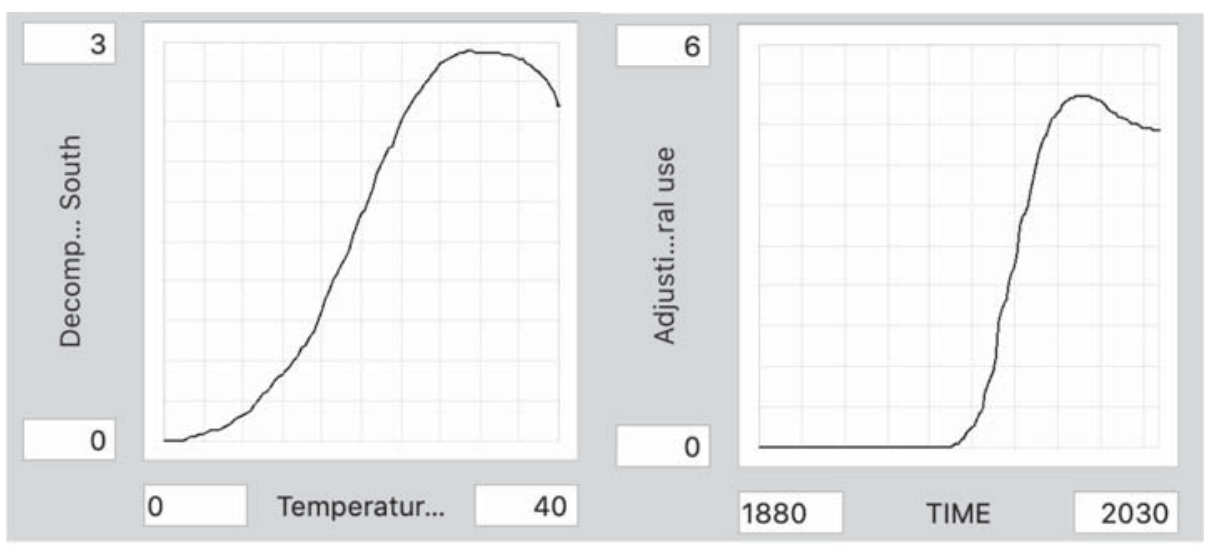

a: Arrhenius

b: Agricultural use

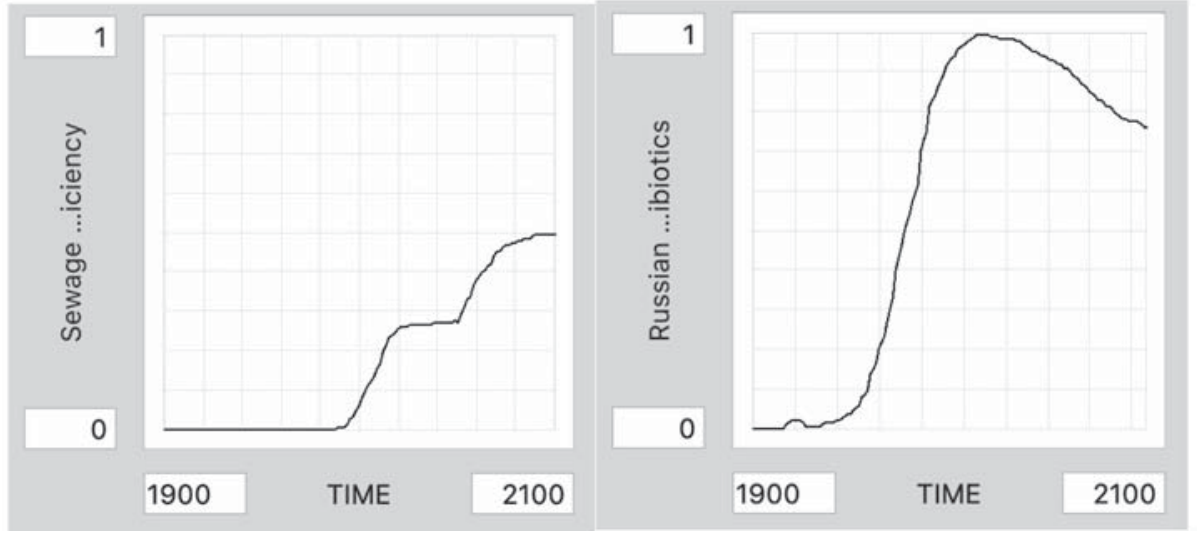

c: Sewage treatment Y

Fig. 13 Further forcinb functions used in the model are shown. a Temperature dependence of antibiotics in water. b Scaling of agricultural use of antibiotics. c Efficiency of Russian

each cure takes $500 \mathrm{mg}$ every day, for 14 days (WHO 2011; Fokin et al. 2011a, b). This was combined with data for infection incidence, measured, assumed, and guessed, and how many of those that would get antibiotics treatment (WHO 2011; Sverdrup et al. 2020). This was back- sewage treatment plants for antibiotics. The annual flow variation varies over the river basin. $\mathbf{d}$ Scaling of Russian use of antibiotics in the Volga River basin

checked on general statistics on per capita use of antibiotics in Russia per capita (van Boeckel et al. 2014; Fokin et al. 2011a, b; Frolova et al. 2020c). There is one total dose module for the Russian part of the river basin. Figure 13a shows the temperature dependence of antibiotics in water.
Fig. 14 The small soil submodel accounting for decomposition and solute transport in the soil

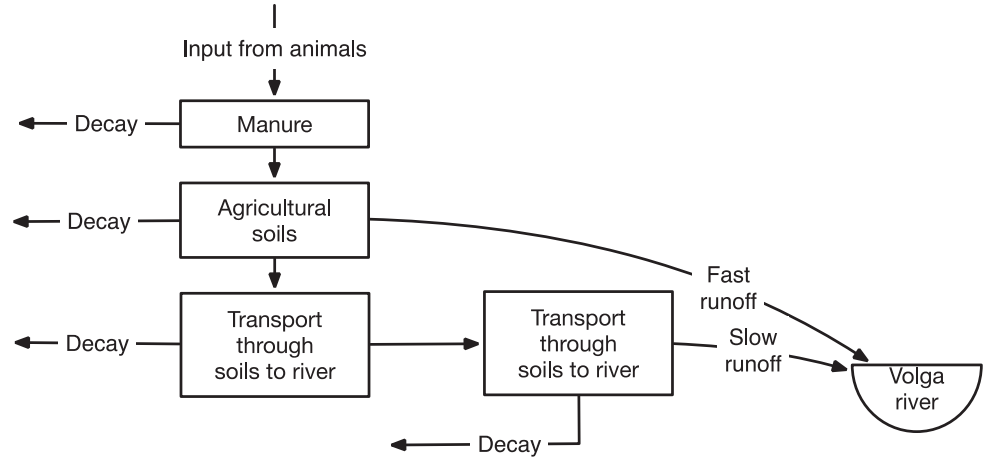


Table 6 Parameterization of the antibiotics resistance risk function

\begin{tabular}{llllllll}
\hline Coefficients, dose in tons per year & Dose order & Amplification order & {$\left[\right.$ Pathogens], $10^{6}$ per ml } & Minimum effect level, [Catalysts], $\mu \mathrm{g} / 1$ \\
\hline $\mathrm{k}_{\text {AUR }}$ & 0.0003 & $\mathrm{a}$ & 1 & - & - & n.a. & - \\
$\mathrm{k}_{\text {MUR }}$ & 0.0001 & $\mathrm{~b}$ & 1 & - & - & n.a. & - \\
$\mathrm{k}_{\text {VRC }}$ & 0.0100 & $\mathrm{n}_{\text {River }}$ & 0.7 & $\mathrm{z}_{\text {River }}$ & 0.5 & n.a. & 0.5 \\
$\mathrm{k}_{\text {Soil }}$ & 0.0030 & $\mathrm{n}_{\text {Soil }}$ & 0.7 & $\mathrm{z}_{\text {Soil }}$ & 0.5 & n.a. & 0.5 \\
\hline
\end{tabular}

Figure $13 \mathrm{~b}$ shows the scaling of agricultural use of antibiotics over time. Figure $13 \mathrm{c}$ shows the assumed efficiency of Russian sewage treatment plants for antibiotics. Figure $13 \mathrm{~d}$ shows the scaling function used for the Russian use of antibiotics over time.

The decomposition rate coefficient was set as an average based on the most used antibiotics reported in the available literature (Chapra and Reckhow 1983; Ingerslev et al. 2001; Ashton et al. 2004; Bhakta and Munekage 2009; Chee-Sanford et al. 2009; Sarmah et al. 2006; Cycon et al. 2019; Pikkemaat et al. 2016; Aldeyab et al. 2008). The rate of decomposition was set at $\mathrm{k}_{\text {Decomposition }}=$ 4 year $^{-1}$, implying that half the amount is gone in 3 months (Cycon et al. 2019). $f(T)$ is the Arrhenius correction for change in temperature, it depends a lot on the decomposing types of bacteria and funghi (Sverdrup and Stjernquist 2002). Figure 14 shows a flowchart for the small soil submodel accounting for decomposition and solute transport in the soil.

For decomposition or metabolization of some antibiotics in the human body, data was found in the WHO 2011 report. They range from 25 to $65 \%$ of the dose to be excreted. As a standard, we have used $35 \%$ of the dose will be excreted. An empirically determined risk function $\mathrm{X}$ applied in the model was estimated, using data from various sources (Bengtsson-Palme and Larsson 2016; Higuera-Llantén et al. 2018; Grenni

Table 7 Parameterization of the simplified antibiotics resistance risk function

\begin{tabular}{llll}
\hline Coefficients & \multicolumn{3}{l}{ Dose order } \\
\hline $\mathrm{k}_{\text {AUR }}$ & 0.0003 & $\mathrm{a}$ & 1 \\
$\mathrm{k}_{\text {MUR }}$ & 0.0001 & $\mathrm{~b}$ & 1 \\
$\mathrm{k}_{\text {VRC }}$ & 0.0100 & $\mathrm{n}_{\text {River }}$ & 0.7 \\
$\mathrm{k}_{\text {Soil }}$ & 0.0030 & $\mathrm{n}_{\text {Soil }}$ & 0.7 \\
\hline
\end{tabular}

et al. 2018; Vishlenkova 2005; Frolova et al. 2020c; Wang et al. 2019; Baranjuk 2019; Pikkemaat et al. 2016), and fitting these to:

$\mathrm{R}=\mathrm{R}_{\text {Environmental }}+\mathrm{R}_{\text {Agricultural }}+\mathrm{R}_{\text {Medical }}$

where $k_{\text {MUR }}$ is the risk coefficient associated with medical use, and $\mathrm{k}_{\mathrm{AUR}}$ is the risk coefficient associated with agricultural use and $\mathrm{k}_{\mathrm{VRC}}$ is the risk associated with elevated concentrations in the Volga river over longer times. We have for the use risks associated with agricultural use and medical use:

$\mathrm{R}_{\text {Agriculture }}=\mathrm{k}_{\mathrm{AUR}}{ }^{*} \mathrm{r}_{\text {Agricultural }}^{\mathrm{a}}$

$\mathrm{R}_{\text {Medical }}=\mathrm{k}_{\text {MUR }} *^{\mathrm{b}} \mathrm{r}_{\text {Medical }}$

For the risk associated with the river concentration is a nonlinear equation combining concentrations that may occur in the river as catalysts as well as the pathogen load in the river being exposed:

$$
\begin{aligned}
\mathrm{R}_{\text {Pollution }}= & \mathrm{k}_{\mathrm{VRC}} \times[\text { Antibiotics }]^{n} \times[\text { Pathogens }] \\
& \times[\text { Catalysts }]^{z}
\end{aligned}
$$

[Antibiotics] is the antibiotics concentration in the river, $n$ is an empirical exponent and $r_{\text {Agricultural }}$ use is the rate of agricultural use in tons per year. [Pathogens] is the water concentration of bacteria being exposed to antibiotics. The pathogen concentration is assumed to be described by a natural background concentration, increasing with temperature from north to south, the amount of animals grazing within $5 \mathrm{~km}$ of the river or its tributaries 
Fig. 15 Causal loop diagram for the decomposition process taking place in a lake water body or in a soil compartment

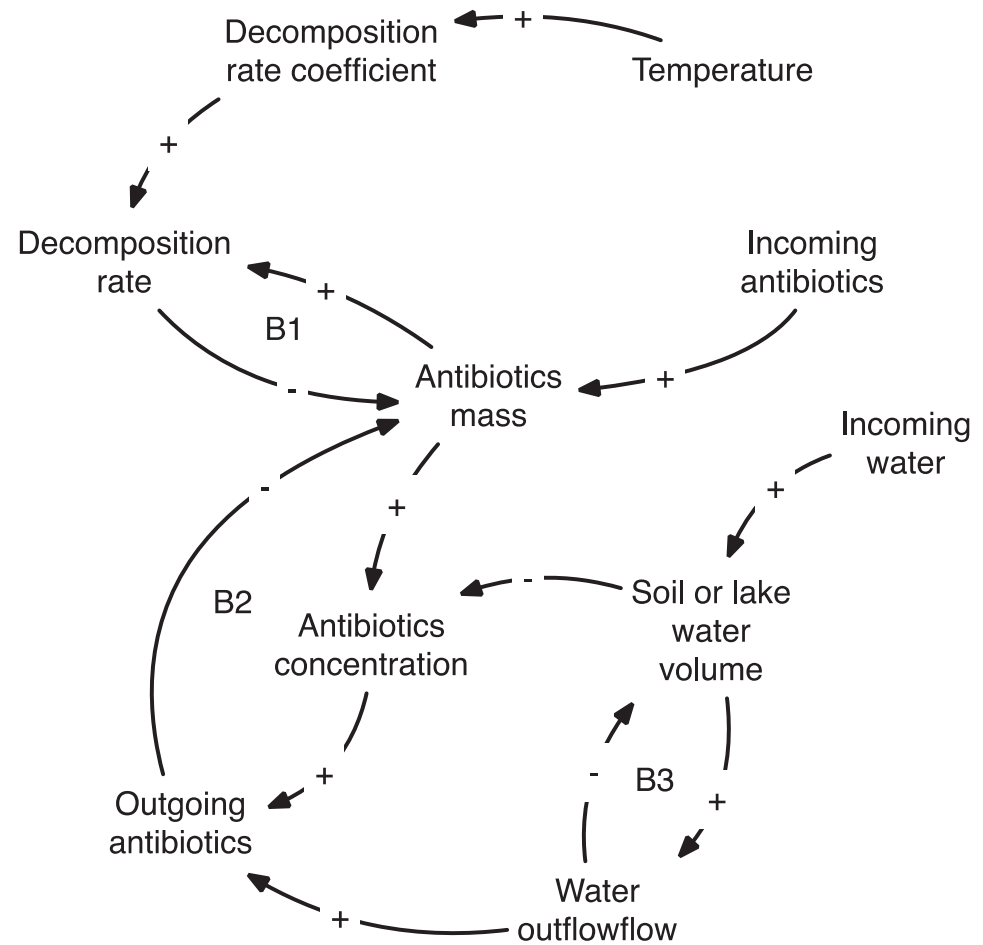

and the amount of untreated sewage from the human populations.

$$
\begin{aligned}
\mathrm{R}_{\text {Soil contamination }}= & \mathrm{k}_{\text {Soil }} \times[\text { Antibiotics }]^{n} \\
& \times[\text { Pathogens }] \times[\text { Catalysts }]^{z}
\end{aligned}
$$

The risk function is based on the antibiotics concentration and the water volume with that concentration. Pathogens are the concentration of potential pathogens, or pathogen interacting microorganisms. [Catalysts] are the concentration of certain chemicals that seems to catalyze the gene transfer involved in intermicrobial gene exchange that transmits resistance (Wang et al. 2019, Baranjuk 2019, Pikkemaat et al. 2016). The chemicals ibuprofen, naproxen, diclofenac, gemfibrozil, and propranolol had this effect in the experiments. They occur in the $\mu \mathrm{g} / \mathrm{l}$ range in many rivers passing heavily populated areas. This resistance promotion occurred even when ibuprofen, naproxen, and gemfibrozil were at concentrations as low as $5 \mu \mathrm{g} / \mathrm{l}$. This is below the lowest bioactive therapeutic dose. The preliminary
Fig. 16 Hydrology. Simulated short-term flow variation 2018 2020 in the Volga River at different nodes

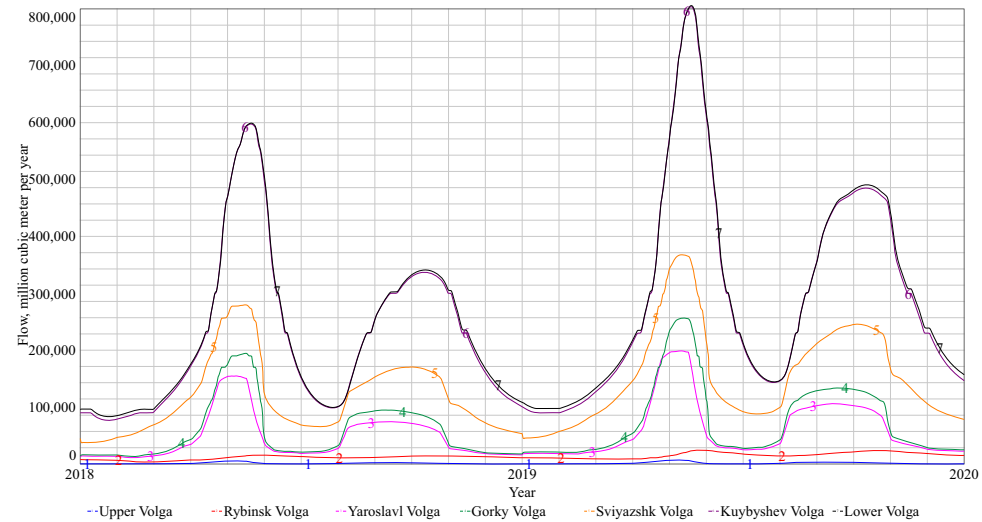


Fig. 17 Hydrology. Simulated water volume in the three largest reservoirs 1930-2050. The blue line is the Rybinsk Reservoir, the red line the Gorkiy Reservoir, and the orange line the Kuybyshev Reservoir. The reservoirs were filled up without major disturbances in the water flow of the Volga

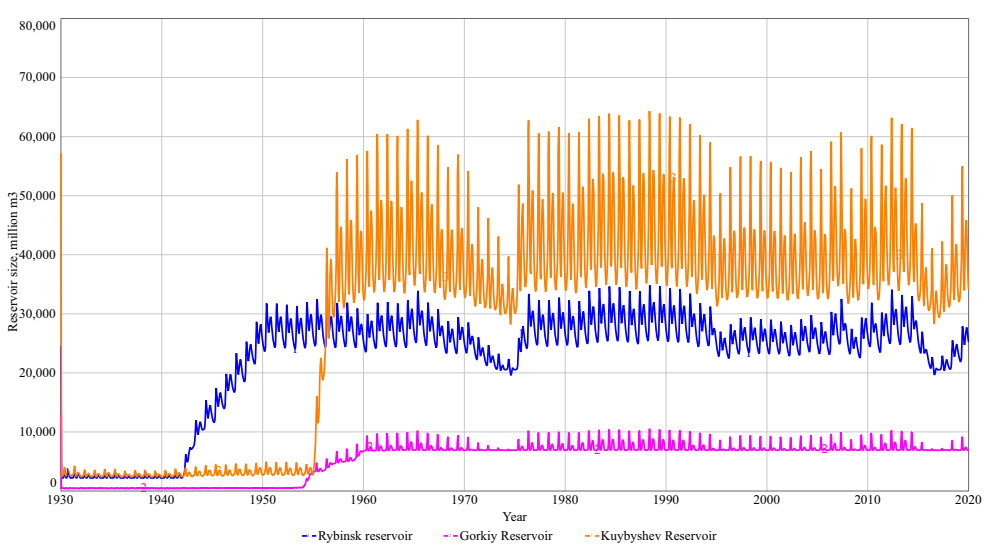

parameterization is shown in Tables 6 and 7. The values may change substantially as more data becomes available (Fig. 15).

Generally, it is assumed that antibiotics resistance development only occur when the antibiotic is in the microbial growth inhibitory concentration range (Wang et al. 2019). This view has changed with results from new research, the findings are that resistance may develop at concentrations several hundred times lower that the lowest microbial growth inhibition concentration. This has been seen both in laboratory research and under field conditions (Pikkemaat et al. 2016; Wang et al. 2019), typical concentrations range from 1 to $0.1 \mu \mathrm{g} / \mathrm{l}$ that will induce resistance (see Table 6). We applied at present a simplified version in the present VOLGA model:
$\mathrm{R}_{\text {Pollution }}=\mathrm{k}_{\mathrm{VRC}} *[\text { Antibiotics }]^{\mathrm{n}}$

Equation (11) has been parameterized in Table 7.

\subsection{The Soil Model and Transit Times in the System}

There are several delays in the system. In the soil, two compartments with 2 and 7 years. Three large reservoirs in the river with about 1-year delay and then the river running the long way in its channel. The river travel time for the water is about 40 days running plus about 1.1 year of delay in the great reservoirs from the source in the Valdai Hills to the Caspian Sea. The antibiotics used in agriculture are to a large degree transported with water through the soil before they reach the Volga. We
Fig. 18 Hydrology. Simulated river level at the big reservoirs of the Volga River. The Rybinsk Reservoir was completed in 1947, the Kuybushev Reservoir in 1954, and the Gorkiy Reservoir in 1955. It can be seen that the target sailing depth is being maintained with very few exceptions; 19511953 in Rybinsk and 1976 and 2017 in the Kuybyshev. The future level drop in the Caspian is mostly due to climate change

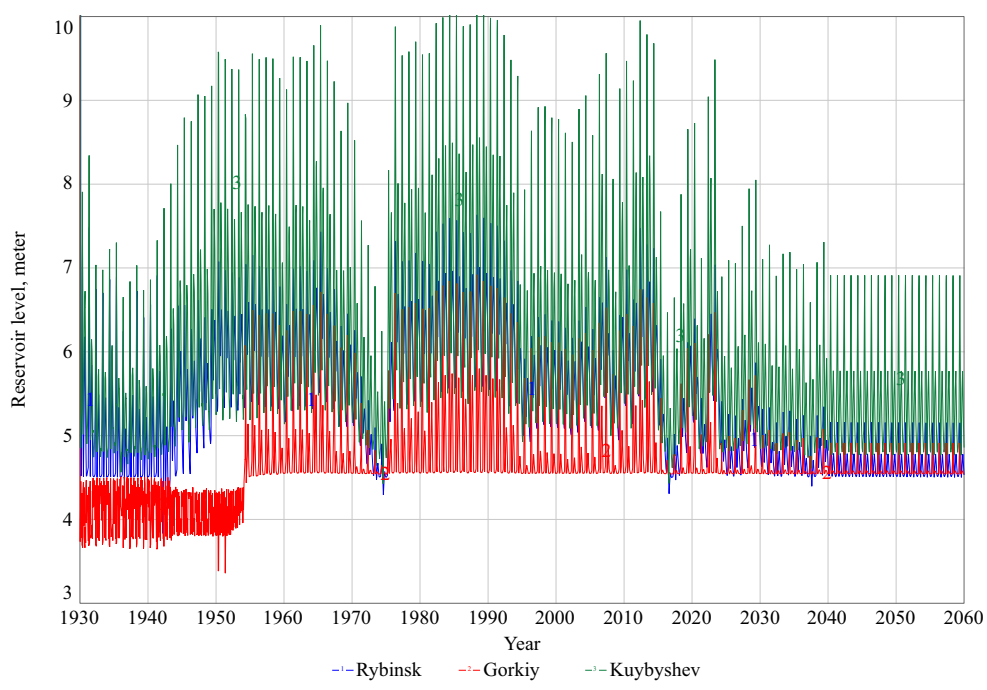




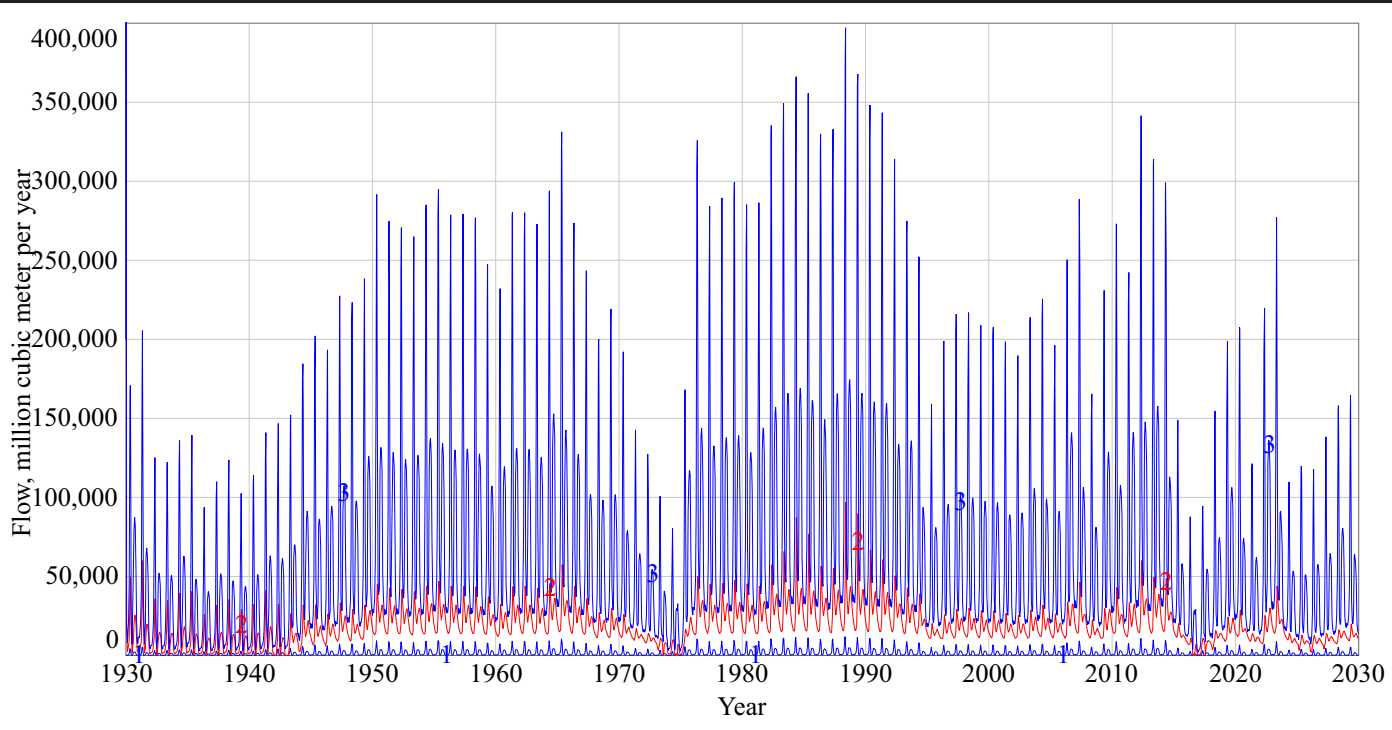

--Upper Volga --Rybinsk Volga --Yaroslavl Volga

In the Northern part of the Volga River Basin

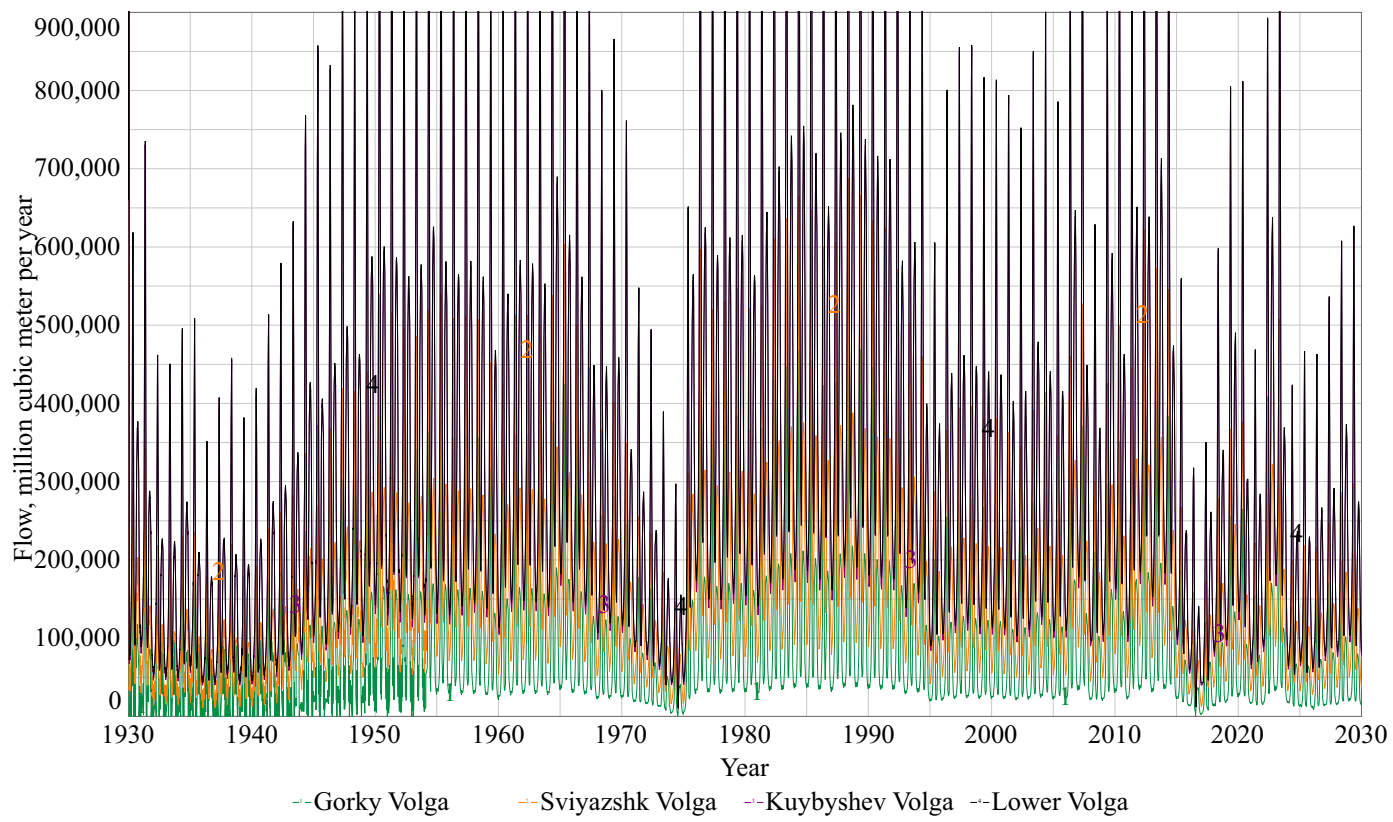

In the Southern part of the Volga River Basin

Fig. 19 Hydrology. Simulated river flow at different nodes in the Volga River 1930-2020. The dips are dry years

have a two-stage model, where the first stage takes 2 years and the second 5 years for the antibiotics to pass. This is shown in the flowchart in Fig. 16. We have assumed that about 5\% drain from the first soil compartment and straight to the river, based on earlier hydrology modelling from a similar climate and landscape in Sweden. Figure 17 shows the causal loop diagram for the decomposition process taking place in a lake water body or in a soil compartment. This principle was used in the compartments shown in Figs. 4 and 14. Only a fraction of this amount will reach the river. The mass balance equation used in the VOLGA model was: 
Fig. 20 The amount simulated with the model to reach the river after having passed through canalization, sewers, or soils before coming to Volga

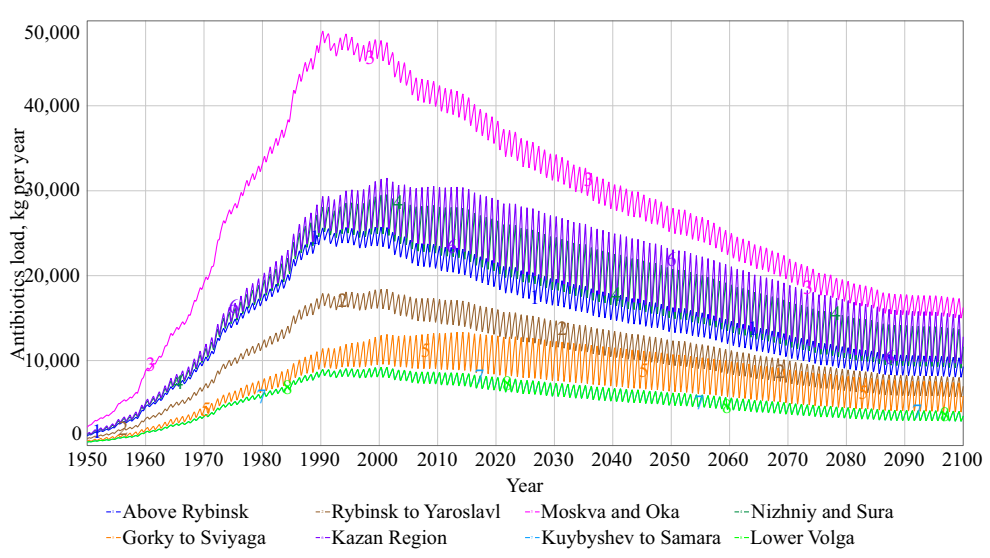

Input to Volga River water = Input to population

$$
\times\left(1-Y_{\text {Metabolic }}\right) \times\left(1-Y_{\text {Sewage }}\right)+
$$

Input to agriculture $\times\left(1-Y_{\text {Metabolic }}\right) \times\left(1-Y_{\text {Runoff }}\right)$

$$
\times\left(1-Y_{\text {Decomposition }}\right) \text {. }
$$

$\mathrm{Y}_{\text {metabolic }}$ is the fraction metabolized by the patient (we assume about $50 \%$, but in many cases, it is as little as $10 \%$, on the average we assume $30 \%$ ) and $\mathrm{Y}_{\text {sewage }}$ is the sewage treatment removal yield, which at present is maximum $30 \%$. The metabolic yield in agriculture is as in people or less, the runoff yield is about $90 \%$ and the decomposition yield is about $50 \%$.

\section{Results}

\subsection{Hydrology of the Volga River}

The results from some of the hydrology simulations are shown in Figs. 16, 17, 18, and 19. Figure 16 shows the simulated short-term flow variation in the Volga River at different nodes. The internal seasonal variations are

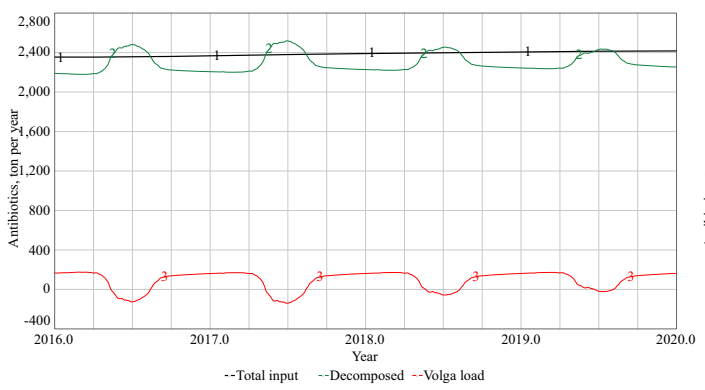

Fig. 21 a Detail of Fig. 23 from 2016 to 2020 . The total input to the river basin (line 1) has been compared to the total decomposed (line 2) and the net flow of antibiotics (line ) that actually reaches the river. b Here, the total input to the Volga River basin has been visible in the simulation, and they are dominated by the regime and volumes in the northern part of the watershed. The water volume increases with the distance travelled down the river. Figure 17 shows the simulated water volume in the three largest reservoirs 1930-2050. The Rybinsk Reservoir was completed in 1947, the Kuybushev reservoir in 1954, and the Gorkiy reservoir in 1955. It can be seen how they fill up after the completion of their construction in 1941, 1954, and 1955.

The size of the reservoirs are so large that they affect the water balance through the increased evaporation from the surfaces in the summer. However, despite their size, they only hold an equlivalent of 3-6-month flow of water in the Volga and are thus only a limited protection against the effects of longer drought.

Figure 18 shows the simulated river level at different nodes in the Volga River. It can be seen that the level is sensitive to not only the seasonal variation but also the long-term variation in rainfall amounts. The original plan for the reservoirs on the Volga had the objective to secure at least 4.5 sailing depth in the river, which is

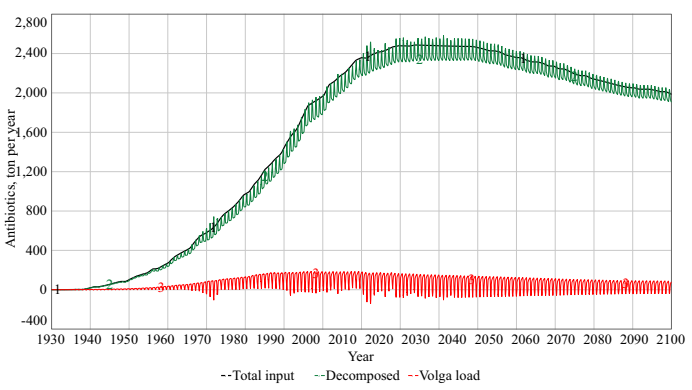

compared to the total decomposed and net flow of antibiotics that actually reaches the river. It is visible that the decomposition removes a substantial part of the antibiotics pollution, but not all over a whole year 

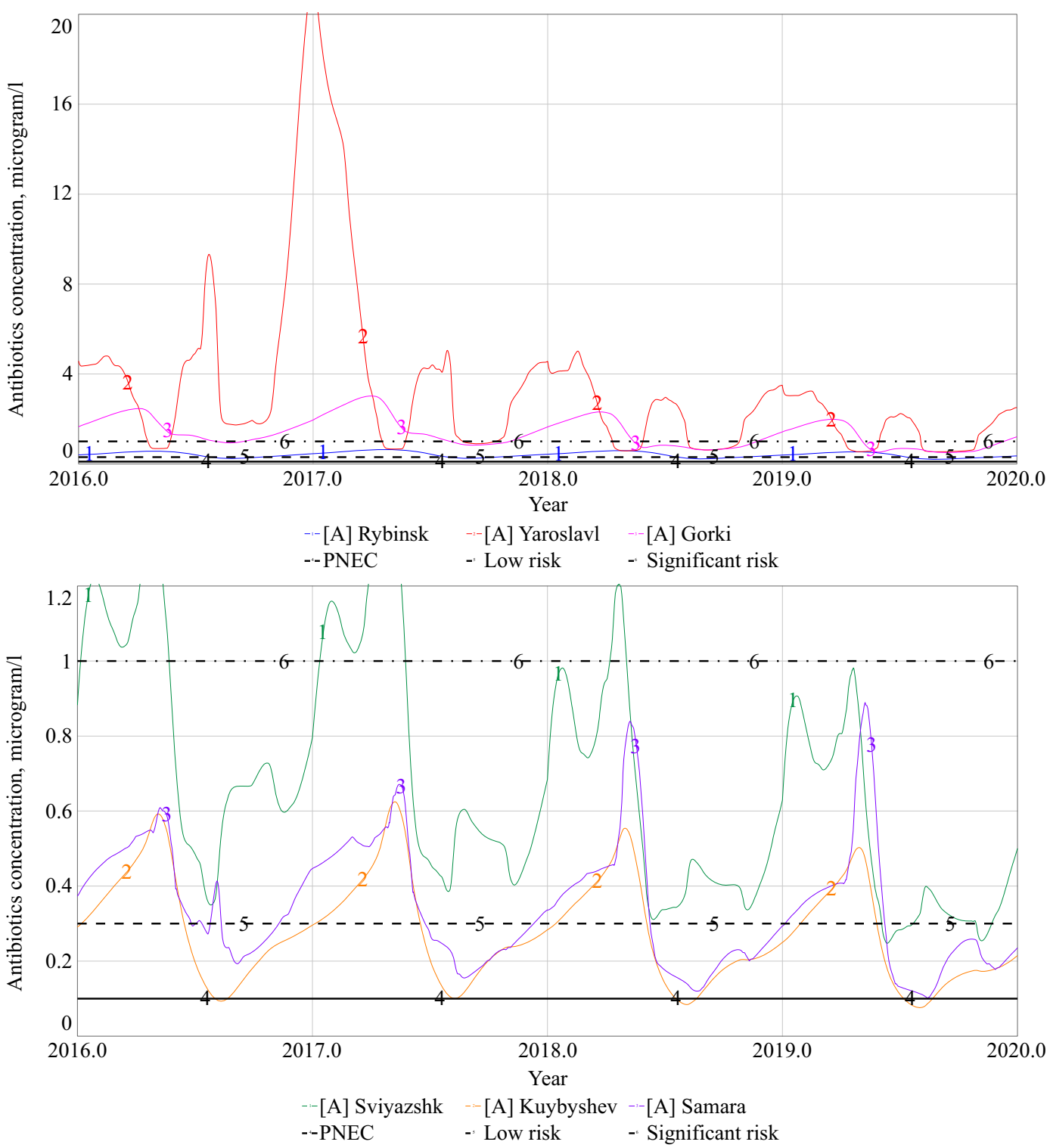

Fig. 22 Antibiotics. Business-as-usual. Simulated antibiotics concentrations in the Volga River at different nodes for 2016-2020. The upper pnanel shows antibiotics concentrations in the upper part of the Volga River, the lower panel shows antibiotics

achived so far at all times. The northern part of the Volga river is frozen from November to April, and then no shipping is possible.

The simulations suggest that droughts as have happend earlier could be handled, but not with much margin left. If climate change were to reduce rainfall further (which is likely), then there would potentially be a seasonal problem with sailing depth during dry seasons or dry years. The dips are dry years. After 2020, concentrations in the lower part of the Volga River. Rybinsk, Yaroslavl, and Gorkiy are all above the PNEC limit on a regular basis. The upper part of the river has higher concentrations than the lower in the simulations

climate change will probably make the southern part of the catchment dry up and recieve less rain. The Volga system is sensitive to that, because with the warming comes also larger losses to evaporation. Figure 19 shows the simulated river flow at different nodes in the Volga River 1930-2020. The dips are dry years. The upper panels hows the northern part of the system, and the lower panel shows the southern part of the system. 

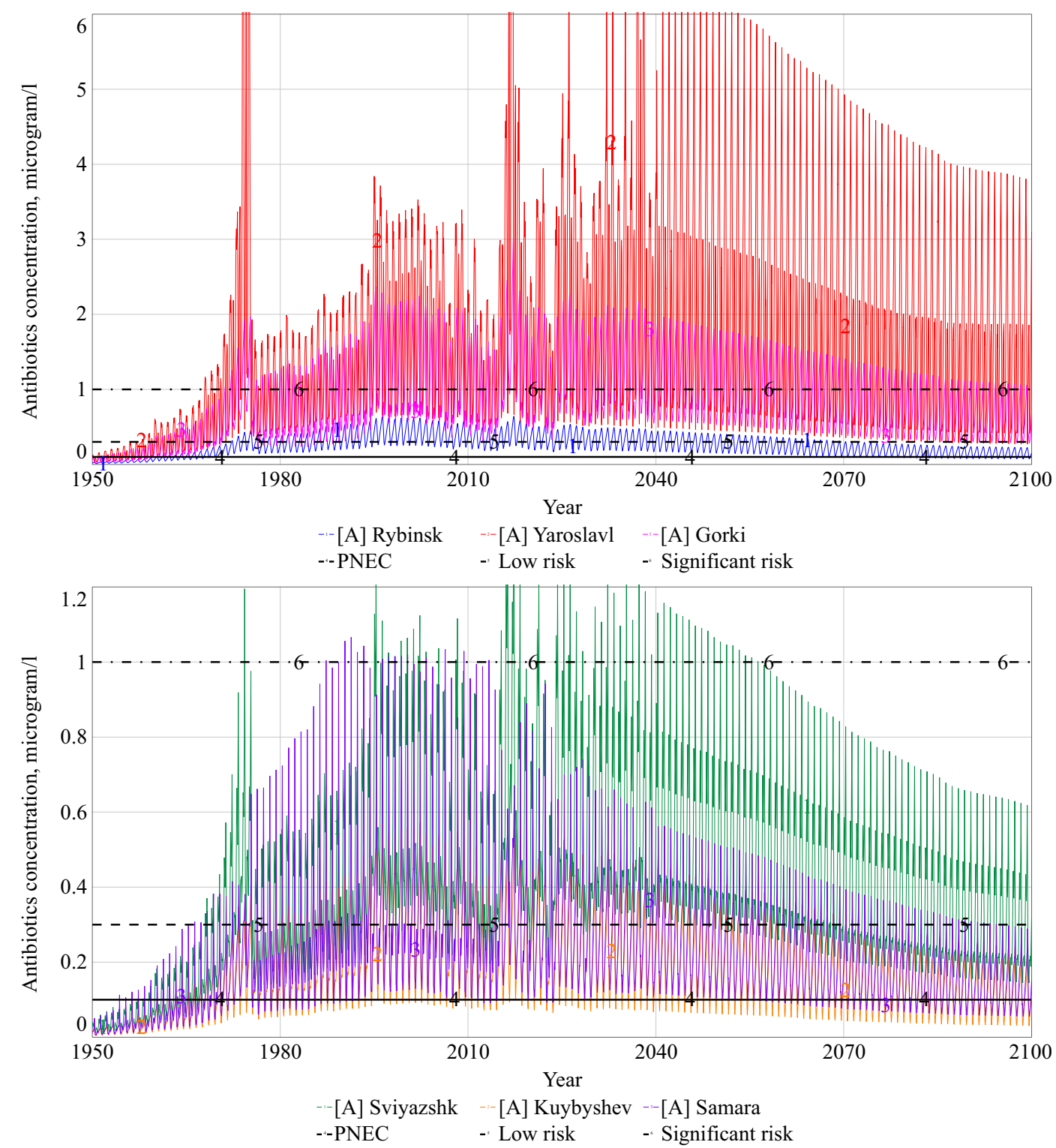

Fig. 23 Antibiotics. Business-as-usual. The graph shows the Volga concentration of antibiotics at different positions on the river 1950-2100 under a business-as-usual scenario. The high concentrations occur at the Oka River node in the Volga River, when all

\subsection{Antibiotics in the Volga River}

\subsubsection{Results for Business-as-Usual}

The results from the simulations are shown in Figs. 20, 21, 22, 23, 24, 25, and 26. Figure 21 shows the amount simulated with the model to reach the river after having passed through canalization, sewers, or soils before coming to Volga and the pollution from Moskva region arrives to the Volga, together with increasing amounts from animal production in the area. The terms PNEC $(0.1 \mu \mathrm{g} / \mathrm{l})$, low risk $(0.5 \mu \mathrm{g} / \mathrm{l})$, and significant risk $(1 \mu \mathrm{g} / \mathrm{l})$ are limits recommended by EU and WHO

the agricultural load has passed the soils, before reaching the river. The variations are caused by the hydrological variations, and by the seasonal variation in antibiotics decomposition in the soils, which is caused by temperature variations. Figure $21 \mathrm{a}$ and $\mathrm{b}$ shows the total input to the river basin has been compared to the net flow of antibiotics that actually reaches the river. The difference has been either decomposed in the soils, or in the 

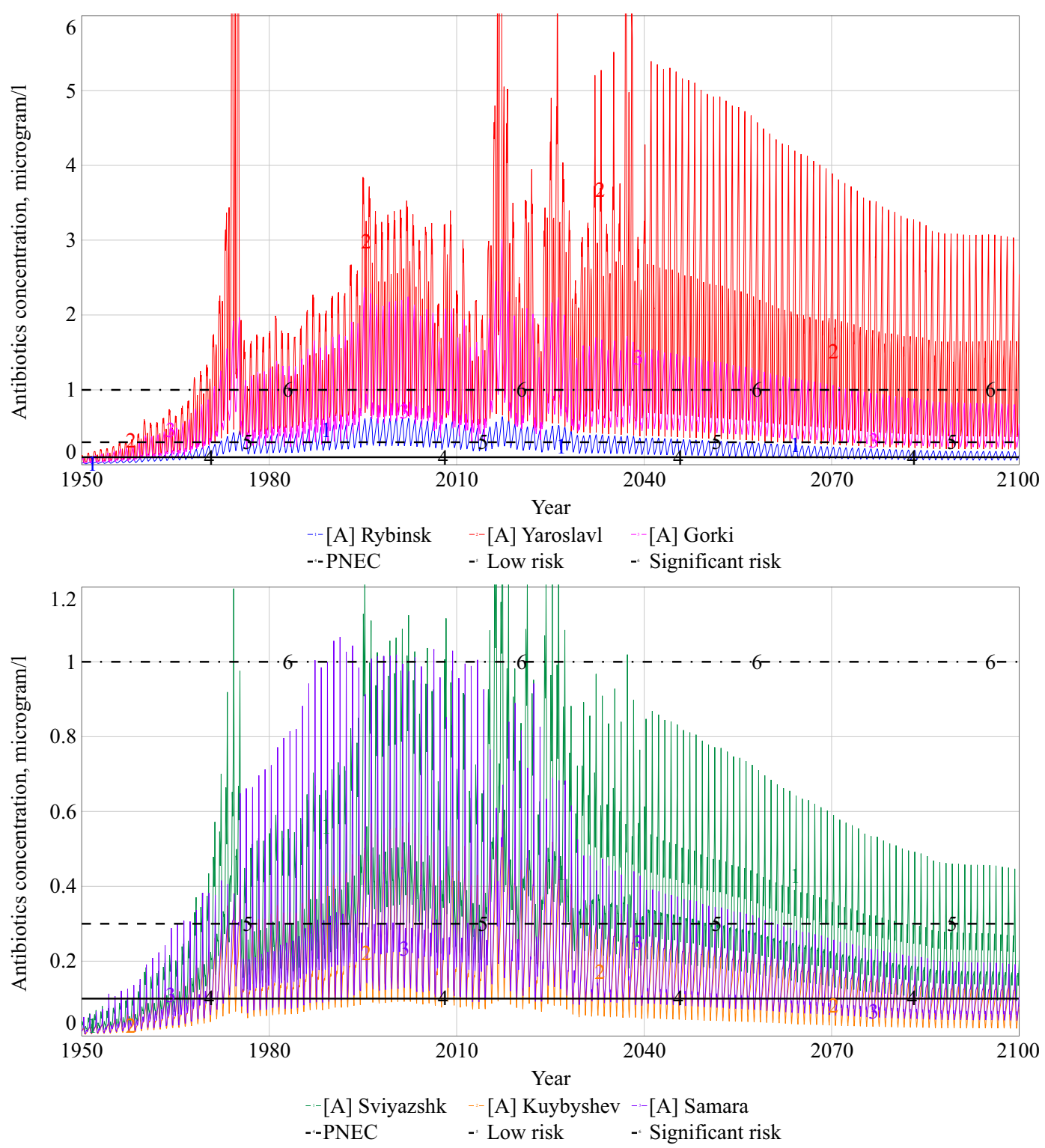

Fig. 24 Antibiotics. Ban all agricultural use. The graph shows the Volga concentration of antibiotics at different positions on the river, assuming a total ban on all use of agricultural use of

river and the reservoirs. The decomposition varies strongly with the antibiotics concentration and the temperature, hence the variation in signal. The negative numbers for the river load that occur (Fig. 21a) suggests that during summer months, the decomposition in soils and the river water is larger than the pollution load reaching the Volga River, and that net removal of antibiotics take place. In the winter, there is a build-up (Fig. 22), as decomposition in slow. Figure 21 shows the antibiotics from 2020 to 2030 , but medical use continue according to business-as-usual after 2020. Banning agricultural use has a significant but not sufficient impact on the water quality

antibitoics concentrations in the Volga River at different nodes for the years 2016 to 2020. The anual variations in antibioticsconcentration can be seen. The concentrations vary a lot thoughout the year and suggests that care must be taken when a river is sampled in order for the set of samples to be representative of the flow. Single samples at random times in a river will be insufficient.

Figure 22 shows the Volga concentration of antibiotics at different positions on the river 1950-2100. 

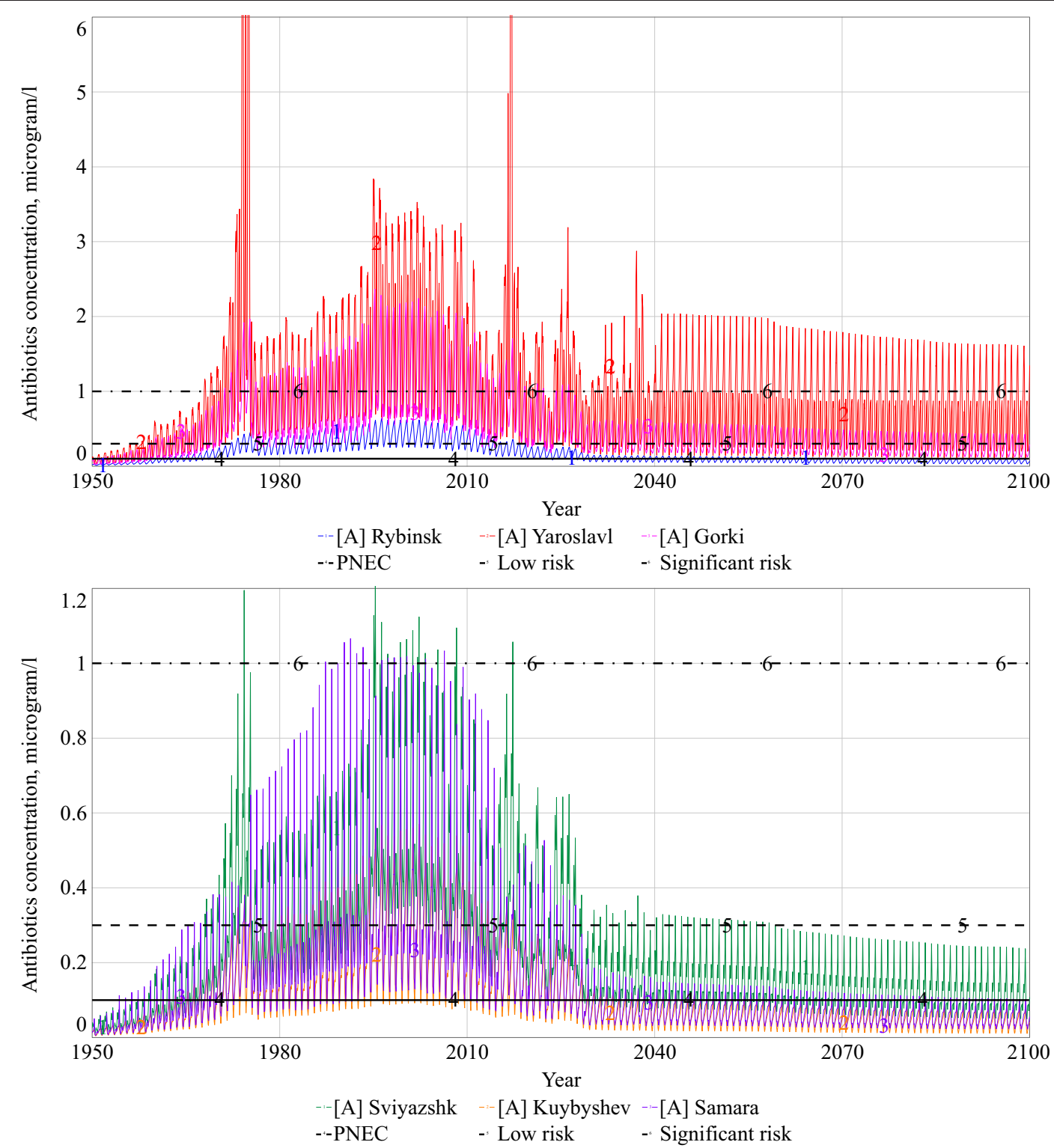

Fig. 25 Antibiotics. Ban all agricultural use and eliminate $90 \%$ of any antibiotics from sewage. The graph shows the Volga concentration of antibiotics at different positions on the river assuming a total ban on all use of agricultural use of antibiotics from 2020 and

The terms "proposed no-effect concentration" (PNEC) is set at $0.1 \mu \mathrm{g} / \mathrm{l}$, "low risk" is set at $0.5 \mu \mathrm{g} / 1$, and "significant risk" is set at $1 \mu \mathrm{g} / \mathrm{l}$; these are limits recommended by EU and WHO. It can be seen that the concentrations in the Volga river is higher that the EU/EEA and WHO recommended limits. The simulations are based on best estimate input values (no real measurements exists in the published scientific literature), and the result needs a $90 \%$ elimination of antibiotics in the sewage treatment plants makes all of Volga comply with the PNEC limit. The medical antibiotics use is assumed to stay the same

to be taken seriously. The higher values occur in dry years, and imply that there is less dilution by rain, and thus larger concentration.

\subsubsection{Results for Alternative Futures}

On advantage of models, is that we may change the conditions in the model and explore what would 
happen. We have tried two different policies with the VOLGA model in addition to business as usual:

1. Ban all use of antibiotics in agriculture.

2. Ban all use of antibiotics in agriculture, and make sure that $90 \%$ of all antibiotics from the medical use is removed before it reaches the river.

We look at the effect on the risk for resistance and the concentrations in the Volga River.

Figure 24 shows the Volga concentration of antibiotics at different positions on the river assuming a total ban on all use of agricultural use of antibiotics from 2020. That would significantly reduce the levels in the Volga to levels below the significant risk limit, but not below the low risk and the PNEC limits. In order to reach safe levels, medical pollution will have to be reduced by $90 \%$.

Figure 25 shows the Volga concentration of antibiotics at different positions on the river assuming a total ban on all use of agricultural use of antibiotics from 2020 and a 90\% elimination of antibiotics in the sewage treatment plants. Note the log delay in the system, the ban and the improved sewage tales place 2020-2030, but the full effect is not seen until 2080. The soils have a long delay, and after many years with high load, antibiotics will leach to the Volga. The levels simulated are below the PNEC limit, but increasing. The drinking water is not yet problematic, but efforts shold be take to secire that antibiotics do not show up in the drinking water in the region.
Fig. 26 The different scenarios used in the sensitivity analysis to investigate the variability in risk of development of antibiotics resistance in the Volga River system
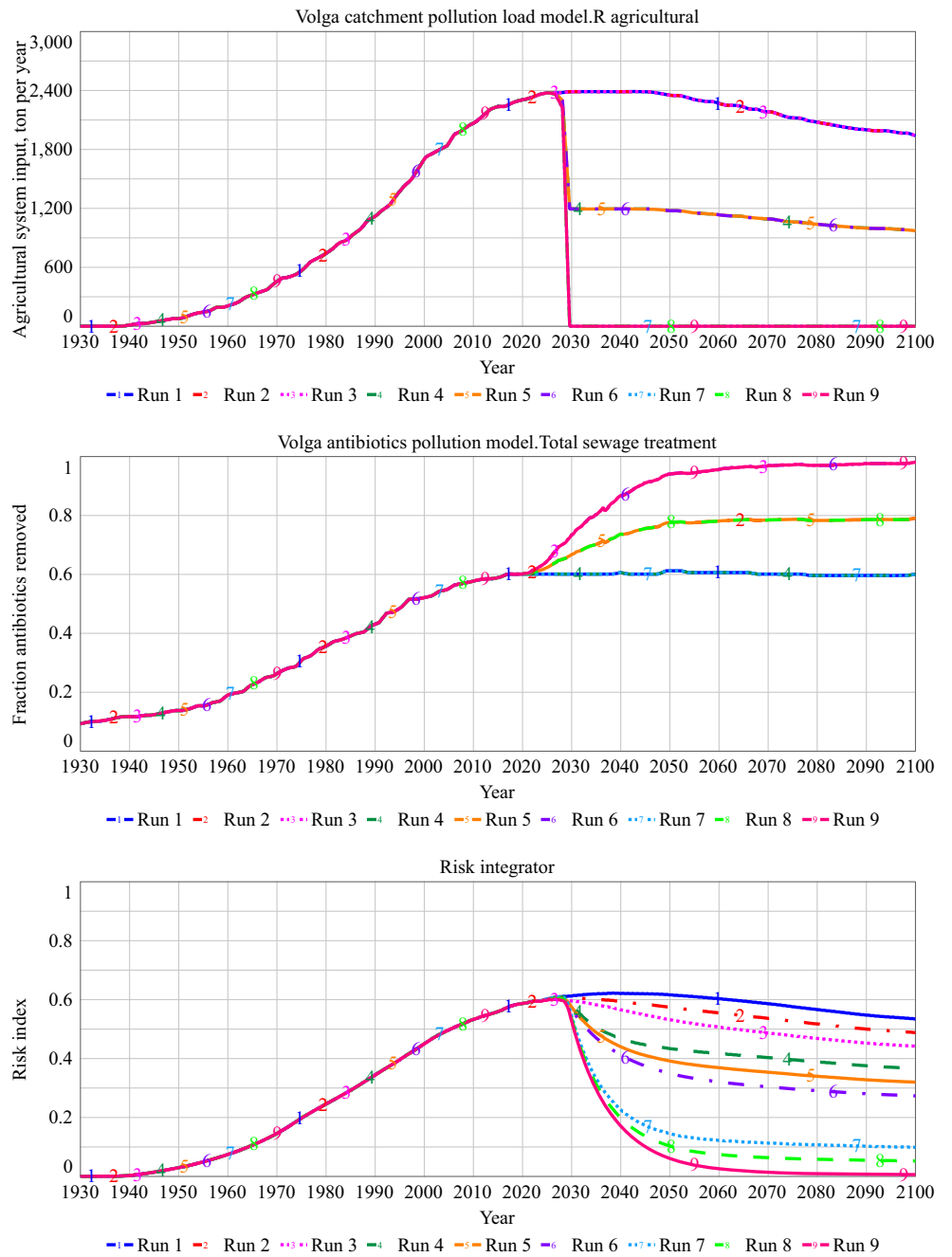


\section{Discussion}

The results were at first appearance experienced as somewhat surprising for the authors, but we realize that it should not have been a surprise when we study the literature on the subject (Boxall and Wilkinson 2019; Wilkinson and Boxall 2019; Ratchina 2015). Our results are not surprising seen in a greater perspective, where similar results have been found in most large cities passing large cities (Greater London; Thames river, Paris; Seine river, Berlin-Elbe river system, Wien-Bratislava-Budapest-Bukarest, Danube river, New York; Hudson river and many more examples (Gilbert 2019, Boxall and Wilkinson 2019, Wilkinson and Boxall 2019). The simulated levels are too high to be long term sustainable. It seems like the largest antibiotics pollution potential problem is on the Moskva and Oka rivers and after they have joined the Volga, but before the next large rivers join the Volga.

It needs to be pointed out that our simulations rest on a number of assumptions that we had no data to properly validate the simulations. We think such data should be collected in the near future (Wilkinson and Boxall 2019). In this respect, this study is explorative and speculative. We conclude that that has been necessary, considering the potential danger and the urgency involved in the issue. Further investigations would lead to the opportunity to redo the simulations with better assumptions, before large scale mitigative measures are undertaken (Behdinan and Hoffmann 2015; Ceccini et al. 2015). There are effective measures that do remove the antibiotics found in both sewage and in the supplied municipal water. Ozonation and electrolytic cell hypochlorite treatment are especially effective, but active carbon filtration seems to work. Prolonged fermentation of sewage sludge reaches reasonable removal rates (ANSES 2011, Bhakta and Munekage 2009, Castiglioni et al. 2006, Cycon et al. 2019, ESAC Yearbook 2009, Paxéus 2004, Vieno et al. 2005, Watkinson et al. 2007, 2010, WHO 2011, 2015b).

\section{Conclusions}

The simulated antibiotics concentrations in the Volga River are compatible with the same level as found in other rivers with high populations and industry density in the catchment as in other parts of the world.
1. The medical antibiotics use has the largest impact, on the antibiotics concentration in the Volga water. Very much of the antibiotics used in agriculture are decomposed in the soil. However, there must be a buffer zone between any operation using antibiotics and any river, lake, or stream of at least $2 \mathrm{~km}$. If this is less, very significant amounts may wash to the river Volga.

2. For the development of antibiotics resistance, the agricultural use is the most important factor, but with a significant risk being caused by the Volga River concentration above the WHO and EU PNEC limits.

3. For a better assessment, fit for policy assessment and mitigation development, more field data on antibiotics inputs and river concentrations are needed.

This suggests that there is potentially a problem in the Volga, and that measures should be taken to avoid antibiotics getting into the drinking water, rivers and soils in the region. We conclude that a prospective survey of the Volga River for antibiotics concentrations would be well justified.

Author Contributions Professor Dr. Harald Sverdrup, Inland University of Applied Science, Hamar, Norway: drafting manuscript and composition of main texts. Volga model conceptualization and programming in the STELLA Architect environment.

Associate Professor Dr. Ludmila L. Frolova, Kazan Federal University, Kazan, Russia: data and information collection, accessing Russian reports and scientific literature and reading databases in Russian only.

Anthoniy Elias Sverdrup, Kazan Federal University, Kazan, Russia: assisted with STELLA Architect programming and basic VOLGA model simulation runs

This was a cooperative research initiative between the Federal University at Kazan, Tatarstan, Russia and the Game School and Interactive simulations, Norwegian Inland University at Hamar, Norway and the Icelandic System Dynamics Center, Industrial Engineering, at the University of Iceland, Reykjavik.

Funding Information Open Access funding provided by Inland Norway University Of Applied Sciences.

Open Access This article is licensed under a Creative Commons Attribution 4.0 International License, which permits use, sharing, adaptation, distribution and reproduction in any medium or format, as long as you give appropriate credit to the original author(s) and the source, provide a link to the Creative Commons licence, and indicate if changes were made. The images or other third party material in this article are included in the article's Creative Commons licence, unless indicated otherwise in a credit line to the material. If material is not included in the article's Creative 
Commons licence and your intended use is not permitted by statutory regulation or exceeds the permitted use, you will need to obtain permission directly from the copyright holder. To view a copy of this licence, visit http://creativecommons. org/licenses/by/4.0/.

\section{References}

Aarestrup, F. M., Seyfarth, A. M., Emborg, H.-D., Pedersen, K., Hendriksen, R. S., \& Bager, F. (2001). Effect of abolishment of the use of antimicrobial agents for growth promotion on occurrence of antimicrobial resistance in fecal enterococci from food animals in Denmark. Antimicrobial Agents and Chemotherapy, 45, 2054-2059.

Aherne, G. W., Hardcastl, E. A., \& Nield, A. H. (1990). Cytotoxic drugs and the aquatic environment: estimation of bleomycin in river and water samples. Journal of Pharmacy and Pharmacology, 42, 741-742 [cited in DWI, 2007].

Albin, S., 1997 Building a system dynamics model; part 1; conceptualization. MIT System Dynamics Education Project (J. Forrester (Ed)). MIT, Boston. 34pp. https://ocw.mit. edu/courses/sloan-school-of-management/15-988-systemdynamics-self-study-fall-1998-spring- 1999 /readings/building.pdf

Alder, A. C., et al. (2006). Consumption and occurrence. In T. A. Ternes \& A. Joss (Eds.), Human pharmaceuticals, hormones and fragrances: The challenge of micropollutants in urban water management. London: IWA Publishing [cited in DWI, 2007].

Aldeyab, M. A., Monnet, D. L., López-Lozano, J. M., Hughes, C. M., Scott, M. G., Kearney, M. P., Magee, E. A., \& McElnay, J. C. (2008). Modelling the impact of antibiotic use and infection control practices on the incidence of hospitalacquired methicillin-resistant Staphylococcus aureus: A time-series analysis. Journal of Antimicrobial Chemotherapy, 62, 593-600.

Allen, H. K., Donato, J., Wang, H. H., Cloud-Hansen, K. A., Davies, J. E., \& Handelsman, J. (2010). Call of the wild: Antibiotic resistance genes in natural environments. Nature Reviews. Microbiology, 8, 251-259.

Andersson, D. I. (2006). The biological cost of mutational antibiotic resistance: Any practical conclusions? Current Opinion in Microbiology, 9, 461-465.

ANSES, (2011). Campagne nationale d'occurrence des résidus de médicaments dans les eaux destinées à la consommation humaine. Ressources en eaux brutes et eaux traitées. Nancy, Agence nationale de sécurité sanitaire de l'alimentation, de l'environnement et du travail, Laboratoire d'Hydrologie de Nancy.

Ashton, D., Hilton, M., \& Thomas, K. V. (2004). Investigating the environmental transport of human pharmaceuticals to streams in the United Kingdom. Science of the Total Environment, 333, 167-184.

Baranjuk, C, (2019). Ibuprofen and other common drugs may help spread antibiotics resistance. New Scientist August 2019 is sue. Read more: https://www.newscientist. com/article/2213067-ibuprofen-and-other-common-drugsmay-help-antibiotic-resistance-spread/\#ixzz5wygEK0z9.
Behdinan, A., \& Hoffman, S. J. (2015). Some global strategies for antibiotic resistance require legally binding and enforceable commitments. The Journal of Law, Medicine \& Ethics, 43(2).

Belkova Y., et al. (2012). Assessment of systemic antimicrobials use and expenditures in Russian multi-profile hospitals: The results of multicenter trial. Proceedings of the 15th ICID. Bangkok, Thailand, June 13-16, 2012.

Belkova Y.A., et al. (2013). Systemic antimicrobials consumption and expenditures in Russian multi-profile hospitals: The results of multicenter trial. Proceedings of the 23nd ECCMID. Berlin, Germany, April 27-30.

Bengtsson-Palme, J., \& Larsson, D. G. J. (2016). Concentrations of antibiotics predicted to select for resistant bacteria: Proposed limits for environmental regulation. Environment International, 86, 140-149.

Bhakta, J. N., \& Munekage, Y. (2009). Degradation of antibiotics (trimethoprim and sulphamethoxazole) pollutants using UV and $\mathrm{TiO}_{2}$ in aqueous medium. Modern Applied Science, 3, 314.

Binder, T., Vox, A., Belyazid, S., Haraldsson, H., Svensson, M., (2003). Developing system dynamics models from causal loop diagrams. 21 pp. https://www.semanticscholar.org/, https://pdfs.semanticscholar.org/cf00/b9084b05ba357bf0c5 fa7a5b9cc1b5695015.pdf.

Boxall, A., and Wilkinson, J. (2019). Identifying hotspots of resistance selection from antibiotic exposure in urban environments around the world. SETAC Europe 29th Annual Meeting, Helsinki, May 27, 2019.

Boxall, A. B., Rudd, M. A., Brooks, B. W., Caldwell, D. J., Choi, K., et al. (2012). Pharmaceuticals and personal care products in the environment: What are the big questions? Environmental Health Perspectives, 120, 1221-1229.

Cassini, A., Högberg, L. D., Plachouras, D., Quattrochi, A., Hoxcha, A., Skov-Simonsen, G., Colomb-Cotinat, M., Kretzschmar, M. E., Devleesschauwer, B., Cecchini, M., Ouakrim, D. A., Oliviera, T. C., Struelens, M. J., Suetens, C., \& Monnet, D. L. (2019). Attributable deaths and disability-adjusted life-years caused by infections with antibiotic-resistant bacteria in the EU and the European Economic Area in 2015: A population-level modelling analysis. Lancet Infectious Diseases, 19, 56-66.

Castiglioni, S., et al. (2006). Removal of pharmaceuticals in sewage treatment plants in Italy. Environmental Science \& Technology, 40, 357-363.

Ceccini, M., Langer, J., \& Slawomirski, L. (2015). Antimicrobial resistance in $G 7$ countries and beyond: Economic issues (75pp). Policies and Options for Action: OECD.

Center for Disease Dynamics, Economics \& Policy. (2015). State of the World's Antibiotics, 2015.84 pages. Washington, D.C: CDDEP.

Chapra, S.C., (1991). Lake and water quality and modelling workshop, NALMS 11th International Symposium, Denver Colorado, Nov 15, 1991, Center for advanced decision support for water and environmental systems.

Chapra S.C. and Reckhow, K.H. (1983). Engineering Approaches for lake management Volume 1. Butterworth Publishers, New York.

Chee-Sanford, J. C., Mackie, R. I., Koike, S., Krapac, I. G., Lin, Y.-F., Yannarell, Y. C., Maxwell, S., \& Aminov, R. I. (2009). Fate and transport of antibiotic residues and antibiotic resistance genes following land application of manure waste. 
Journal of Environmental Quality, 38, 1086-1108. https://doi.org/10.2134/jeq2008.0128.

Chen, Y., Chen, H., Zhang, L., Jiang, Y., Yew-Hoong Gin, K., \& He, Y. (2018). Occurrence, distribution, and risk assessment of antibiotics in a subtropical river-reservoir system. Water, 10, 104-120. https://doi.org/10.3390/w10020104.

Climate date.org 2020. https://en.climate-data.org/asia/russianfederation/yaroslavl-oblast/volga-282140/.

Cogliani, C., Goossens, H., \& Greko, C. (2011). Restricting antimicrobial use in food animals: Lessons from Europe. Microbe, 6, 274-280.

Cycon, M. C., Mrozik, A., \& Piotrowska-Segel, Z. (2019). Antibiotics in the soil environment-Degradation and their impact on microbial activity and diversity. Frontiers in Microbiology, 10, 338-382.

Davies, J., \& Davies, D. (2010). Origins and evolution of antibiotic resistance. Microbiology and Molecular Biology Reviews, 74, 417-433.

de Kraker, M. E. A., Stewardson, A. J., \& Harbarth, S. (2016). Will 10 million people die a year due to antimicrobial resistance by 2050 ? PLoS Medicine, 13, e1002184.

Domagk, G. (1935). Eine neue Klasse von Desinfektionsmitteln. Deutche Medicinische Wochenschrift., 61, 250-253.

Dunaev, I. I. (1833). Results of chemical analysis of Volga and Kaban water. Zavolzhsky Ant, 3, 1149.

Economou, V., \& Gousia, P. (2015). Agriculture and food animals as a source of antimicrobial-resistant bacteria. Infection and Drug Resistance., 8, 49-61. https://doi.org/10.2147/IDR. S55778.

Emerson de Lima Procopio, R., Reis da Silva, I., Martins, M. K., Lucioo de zevedo, J., \& Magali de Araujo, J., (2012). Atibiotics produced by streptomycetes. The Brazilian Joyrnal of Infectuous Diseases, 16, 466-471.

ESAC Yearbook (2009). Available from: http://ecdc.europa. e u/en/a ctivities/surveillance/ES A C Net/publications/Documents/.

Fair, R. J., \& Tor, Y. (2014). Antibiotics and bacterial resistance in the 21st century. Perspectives in Medicinal Chemistry, 6, 2564.

Filtzer, D. (2008). Poisoning the proletariat: Urban water supply and river pollution in Russia's industrial regions during late Stalinism, 1945-1953. Acta Slavica Iaponica, 26, 85-108.

Flanders Investment and Trade (2018). An overview of the meat sector in the Russian and North-West Region 2017. 11 page report from Flanders investment and trade, Brussels.

Fleming, A. (1929). On the antibacterial action of cultures of a penicillium, with special reference to their use in the isolation of $B$. influenzae. Bulletin of the World Health Organization, 79, 780-790.

Fokin, A.A., et al. (2011a). Patterns of antimicrobials usage in surgical infection units in 5 Russian cities. Proceedings of the $27^{\text {th }}$ ICPE, Chicago, USA, August 14-17, 2011.

Fokin A.A., et al. (2011b) Comparison of consumption and expenditures for systemic antimicrobials in ICUs of 6 Russian cities. Proceedings of the $27^{\text {th }}$ ICPE, Chicago, USA, August 14-17, 2011.

Forrester, J. W. (1971). World dynamics. Waltham: Pegasus Communications.

Frolova, L.L., Sverdrup, A.E., Sverdrup, H.U. (2020a). Developing a system dynamics model for the Nizhniy and Sredniy Kaban Lakes, assessing the impacts of phosphorus and nitrogen inputs to the lakes. Water Air and Soil Pollution. 21 pages. In review.

Frolova, L.L., Sverdrup, A.E., Sverdrup, H.U. (2020b). Modelling the hydrology dynamics of the Nizhniy and Sredniy Kaban Lakes. Water Air and Soil Pollution. 21 pages. In review,

Frolova, L.L., Sverdrup, A.E., Sverdrup, H.U. 2020c. Using the Kaban Lakes integrated assessment model for investigation potential levels of antibiotics pollution of the Nizhniy and Sredniy Kaban Lakes. Water Air and Soil Pollution. 21 pages. In review.

Gabdulhakova, O. I., Lukyanova, A. V., \& Stratilatova, I. I. (2016). Social and ecological risks of the petrochemical industry development. Journal of Environmental Management \& Tourism, 7, 399-406. https://doi. org/10.14505/jemt.v7.3(15).05.

Gaynes, R. (2017). The discovery of penicillin - New insights after more than 75 years of clinical use. Emerging Infectious Diseases, 23, 849-853.

Gilbert, N. (2019). World's rivers 'awash with dangerous levels of antibiotics. Largest global study finds the drugs in two-thirds of test sites in 72 countries. Guardian, Monday, 27. May, Newspaper article referring to an article in the Lancet. https://www.theguardian.com/society/2019/may/27/worldsrivers-awash-with-dangerous-levels-of-antibiotics

Gilchrist, M. J., Greko, C., Wallinga, D. B., Beran, G. W., Riley, D. G., \& Thorne, P. S. (2006). The potential role of concentrated animal feeding operations in infectious disease epidemics and antibiotic resistance. Environmental Health Perspectives, 115, 313-316.

Gorelits, O. \& Zemyanov, I. (2017). The Volga River Basin history of development and modern hydrological regime under the changing climate. Federal Service on Hydrometeorology and Environmental Monitoring of the Russian Federation, Zubov State Oceanographic Institute. Conference powerpoint presentation, Hydrological Conference Roma.

Greenfield, B. K., Shaked, S., Marrs, C. F., Nelson, P., Raxter, I., Xi, C., McKone, T. E., \& Jolliet, O. (2018). Modeling the emergence of antibiotic resistance in the environment: An analytical solution for the minimum selection concentration. Antimicrobial Agents and Chemotherapy, 62, e01686e01617. https://doi.org/10.1128/AAC.01686-17.

Grenni, P., Ancona, V. A., \& Caracciolo, A. B. (2018). Ecological effects of antibiotics on natural ecosystems: A review. Microchemical Journal, 136, 25-39.

Gualerzi, C.O., Brandi, L, Fabbretti, A, Pon C.L. 2013. Antibiotics: Targets, Mechanisms and Resistance. John Wiley \& Sons.. ISBN 9783527333059.

Halling-Sørensen, B., Nors Nielsen, S., Lansky, P. E., Ingerslev, F., Holten Lützhøft, H. C., \& Jørgensen, S. E. (1998). Occurrence, fate and effects of pharmaceutical substances in the environment - a review. Chemosphere, 36, 357-393.

Haraldsson, H. (2004). Introduction to systems thinking and causal loop diagrams. Reports in Ecology and Environmental Engineering 1:2004 (5th ed.). Lund: Lund University.

Haraldsson, H. and Sverdrup, H., (2005), On aspects of systems analysis and dynamics workflow. Proceedings of the systems dynamics society, July 17-21, 2005 International Conference on systems dynamics, Boston, USA. 10 pages. http://www. s y s t e m dy n a mi c s.org/con ferences/2005 /proceed/papers/HARAL310.pdf. 
Heberer, T., Schmidt-Bäumler, K., \& Stan, H. J. (1998). Occurrence and distribution of organic contaminants in the aquatic system in Berlin. Part II: Substituted phenols in Berlin surface water. Acta Hydrochimica et Hydrobiologica, 26, 272-278.

Heilig, S., Lee, P., \& Breslow, L. (2002). Curtailing antibiotic use in agriculture. It is time for action: this use contributes to bacterial resistance in humans. The Western Journal of Medicine, 176, 9-11.

Heinemann, J. A., Ankenbauer, R. G., \& Amábile-Cuevas, C. F. (2000). Do antibiotics maintain antibiotic resistance? Drug Discovery Today, 5, 195-204.

Higuera-Llantén, S., Vásquez-Ponce, F., Barrientos-Espinoza, B., Mardones, F. O., Marshall, S. H., \& Olivares-Pacheco, J. (2018). Extended antibiotic treatment in salmon farms select multiresistant gut bacteria with a high prevalence of antibiotic resistance genes. PLoS One, 13(9), e0203641. https://doi. org/10.1371/journal.pone.0203641.

Houghton, E. (2018). Russia rapidly increasing meat production volume. The Pig Site. https://thepigsite.com/news/2018/04 /russia-rapidly-increasing-meat-production-volume-1

Hurd, H.S., Doores, S., Hayes, D., Mathew, A., Maurer, J., Silley, P., Singer, P.S., \& Jones, R. N. (2004). Public health consequences of macrolide use in food animals: a deterministic risk assessment. Journal of Food Protection, 67(5), 980-9.

Hutchinson, J. M., Patrick, D. M., Marra, F., Ng, H., Bowie, W. R., Heule, L. H., Muscat, M., \& Monnet, D. L. (2004). Measurement of antibiotic consumption: A practical guide to the use of the anatomical therapeutic chemical classification and defined daily dose system methodology. Canada. Canadian Journal of Infectious Diseases, 15, 29-35.

Index Mundi. (2019). Russian Federation animal numbers. https://www.indexmundi.com/agriculture/?country= ru\&commodity=cattle \&graph=production.

Ingerslev, F., Toräng, L., Loke, M. L., Halling-Sørenson, B., \& Nyholm, N. (2001). Primary biodegradation of veterinary antibiotics in aerobic and anaerobic surface water simulation systems. Chemosphere, 44, 865-872.

Interagency Coordination Group on antimicrobial resistance. (2019). No time to wait: Securing the future from drugresistant infections. Report to the Secretary-General of the United Nations, UN, New York, 28 pages.

Jones, O. A., Lester, J. N., \& Voulvoulis, N. (2005). Pharmaceuticals: a threat to drinking water? Trends in Biology, 23, 163-167.

Kalimullin, A.M. (2005). Environmental issues in context of industrial growth of Tatarstan Republic in the late 1960thearly 1990th. Kazan University.

Kalimullin, A. M., \& Vinogradov, V. V. (2015). Ecological and Sanitary Problems of Kazan Province Industrial Development in the XIX $^{\text {th }}$ and Early $\mathrm{XX}^{\text {th }}$ Centuries. Review of European Studies, 7(1), 2015 ISSN 1918-7173.

Kim, D. H. (1992). Toolbox: Guidelines for Drawing Causal Loop Diagrams. The Systems Thinker, 3, 5-6.

Kirchelle, C. (2018). Pharming animals: a global history of antibiotics in food production (1935-2017). Palgrave Communications, 4(96), 1-13. https://doi.org/10.1057 /s41599-018-0152-2 www.nature.com/palcomms.

Kirchhelle, C. (2019). Pyrrhic progress. Antibiotics in AngloAmerican food production 1935-2013. Newark: Rutgers University Press.
Klein, E. Y., van Broeckel, T. P., Matinez, E. M., Pant, S., Gandre, S., Levin, S., Goossens, H., \& Laxminarayan, R. (2017). Global increase and geographic convergence in antibiotic consumption between 2000 and 2015. Proceedings of the National Academy of Sciences, 115, E3463-E3470.

Krestovnikov, N.K. (1870). Industry and trade turnovers of Kazan. Kazan University.

Landers, T., Cohen, B., Wittum, T. E., \& Larson, E. L. (2012). A Review of Antibiotic Use in Food Animals: Perspective, Policy, and Potential. Public Health Reports, 127, 4-23.

Laxminarayan, R., Duse, A., Wattal, C., Zaidi, A. K., Wertheim, H. F., Sumpradit, N., Vlieghe, E., Hara, G. L., Gould, I. M., Goossens, H., Greko, C., So, A. D., Bigdeli, M., Tomson, G., Woodhouse, W., Ombak, A. E., Peralta, A. Q., Qamar, F. N., Mir, F., Kariuki, S., Bhutta, Z. A., Coates, A., Bergstrom, R., Wright, G. D., Brown, E. D., \& Cars, O. (2013). Antibiotic resistance-the need for global solutions. The Lancet Infectious Diseases., 13, 1057-1098.

Leekha, S., Terrell, C. L., Edson, R. S. (2011). General principles of antimicrobial therapy. Mayo Clinic Proceedings 86, 156167. https://doi.org/10.4065/mcp.2010.0639.

Ling, L. L., Schneider, T., Peoples, A. J., Spoering, A. L., Engels, I., Conlon, B. P., Mueller, A., Schäberle, T. F., Hughes, D. E., Epstein, S., Jones, M., Lazarides, L., Steadman, V. A., Cohen, D. R., Felix, C. R., Fetterman, K. A., Millett, W. P., Nitti, A. G., Zullo, A. M., Chen, C., \& Lewis, K. (2015). A new antibiotic kills pathogens without detectable resistance. Nature, 517, 455-459.

Lyons, G., (2014). Pharmaceuticals in the environment: a growing threat to our tap water and wildlife. A CHEM Trust report 36 pages.

Marshall, B. M., \& Levy, S. B. (2011). Food Animals and Antimicrobials: Impacts on Human Health. Clinical Microbiology Reviews, 24, 718-733.

Meadows, D. L., Behrens III, W. W., Meadows, D. H., Naill, R. F., Randers, J., \& Zahn, E. K. O. (1974). Dynamics of Growth in a Finite World. Massachusetts: Wright-Allen Press, Inc..

Moisenko, N. N. (1994). Antibiotic-resistant enterobacteria in sewage and the water of surface reservoirs. Antibiotiki $i$ Khimioterapiia, 39, 64-68.

Obukhova, O. V., \& Lartseva, L. V. (2014). Features of antibiotic resistance of enterobacteria in the Volga River delta. Gigiena i Sanitariia, 3, 21-23.

Obukhova, O. V., \& Lartseva, L. V. (2018). Ecological characteristics of antibiotic resistance of conditionally pathogenic microorganisms persistent in hydroecosystems. Proceedings of Astrakhan State Technical University. Series: Fishing Industry, 53-57. https://doi.org/10.24143/2073-5529-20184-53-57.

Paxéus, N. (2004). Removal of selected non-steroidal anti-inflammatory drugs (NSAIDs), gemfibrozil, carbamazepine, $\beta$ blockers, trimethoprin and triclosan in conventional wastewater treatment plants in five EU countries and their discharge to the aquatic environment. Water Science and Technology, 50, 253-260.

Penesyan, A., Gillings, M., \& Paulsen, I. (2015). Antibiotic discovery: Combatting bacterial resistance in cells and in biofilm communities. Molecules, 2015(20), 5286-5298.

Phillips, I., Casewell, M., Cox, T., de Groot, B., Friis, C., Jones, R., Nightingale, C., Preston, R., \& Waddell, J. (2003). Does the use of antibiotics in food animals pose a risk to human 
health? A critical review of published data. The Journal of Antimicrobial Chemotherapy, 53, 28-52.

Pikkemaat, M.G., H. Yassin, H.J. van der Fels-Klerx and B.J.A. Berendsen, (2016). Antibiotic residues and resistance in the rnvironment. Wageningen, RIKILT Wageningen University and Research Centre, RIKILT report 2016.009. 32 pp.; 1 fig.; 0 tab.; 179 ref.

Podolsky, S. H. (2018). The evolving response to antibiotic resistance (1945-2018). Palgrave Communications, 4, 124-132. https://doi.org/10.1057/s41599-018-0181-x www.nature. com/palcomms.

Price, L. B., Koch, B. J., \& Hungate, B. A. (2015). Ominous projections for global antibiotic use in food-animal production. Proceedings of the National Academy of Sciences, 112, 5554-5555.

Ratchina, S. (2015). Antibiotic use surveillance in Russia: current state and prospects for collaboration, Moscow, 18 December, 201523 pages ppt presentation. Smolensk, Russian Federation: Inter-regional Association for Clinical Microbiology \& Antimicrobial Chemotherapy.

Ratchina S.A., et al. (2009). Optimization of systemic antimicrobials usage in multi-profile hospitals in Russian Federation. Proceedings of the 19th ECCMID. Helsinki, Finland, May 16-19.

Roberts, N., Andersen, D. F., Deal, R. M., \& Shaffer, W. A. (1982). Introduction to Computer Simulation: A System Dynamics Approach. Chicago: Productivity Press.

Sarmah, A. K., Meyer, M. T., \& Boxall, A. B. A. (2006). A global perspective on the use, sales, exposure pathways, occurrence, fate and effects of veterinary antibiotics (VAs) in the environment. Chemosphere, 65, 725-759.

Senge, P. (1990). The fifth discipline. The art and practice of the learning organisation. New York: Century Business.

Senge, P. M., Smith, B., Schley, S., Laur, J., \& Kruschwitz, N. (2008). The Necessary Revolution: How Individuals and Organizations Are Working Together to Create a Sustainable World. London: Doubleday Currency.

Shea, K. M. (2003). Antibiotic Resistance: What Is the Impact of Agricultural Uses of Antibiotics on Children's Health? Pediatrics, 112, 253-258.

Silbergeld, E. K., Graham, J., \& Price, L. B. (2008). Industrial food animal production, antimicrobial resistance, and human health. Annual Review of Public Health, 29, 151-169.

Sverdrup, H., \& Stjernquist, I. (Eds.) (2002). Developing principles for sustainable forestry, Results from a research program in southern Sweden. Managing Forest Ecosystems 5, 566 pp, Kluwer Academic Publishers, Amsterdam.

Sverdrup, H. (Ed.), Haraldsson, H., Olafsdottir, A.H., Belyazid, S. (2018). System Thinking, System Analysis and System Dynamics: Find out how the world works and then simulate what would happen. 3rd revised edition. Háskolaprent Reykjavik. 310 pp. ISBN 978-9935-24-425-3.

Sverdrup, H.U., Olafsdottir, A.H., Wood, T.R., Christie, W.H., (2020) Modelling global mortality dynamics including infectious disease, environmental pollution, nutrition, health status and the use of antibiotics in health care and agriculture. Journal of Gnomes and Goblins (In review).

Tan, S.Y., \& Tatsumura, Y., (2015). Alexander Fleming (18811955): Discoverer of penicillin. Singapore Medical Journal $56,366-367$.
USDA Foreign Agricultural Service (2017). Russian Federation. Livestock and Products Annual Russia 2017 Livestock and Products Annual. GAIN Report Number RS1757. 31 pages.

van Boeckel, T.P., (2018). Global trends in antimicrobial use. ETH, Zürich, Switzerland. 40 pages power-point presentation. thomas.van.boeckel@gmail.com.

van Boeckel, T. P., Gandre, S., Ashok, A., Caudon, Q., Grenfell, B., Levin, S. A., \& Laxminarayan, R. (2014). Global antibiotic consumption 2000 to 2010: An analysis of national pharmaceutical sales data. Lancet, 14, 742-751.

van Boeckel, T. P., Brower, C., Gilbert, M., Grenfell, B. T., Levin, S. A., Robinson, T. P., Teillant, A., \& Laxminarayan, R. (2015). Global trends in antimicrobial use in food animals. Proceedings of the National Academy of Sciences, 112, 5649-5654.

van Bunnik, B. A. D., \& Woolhouse, M. E. J. (2017). Modelling the impact of curtailing antibiotic usage in food animals on antibiotic resistance in humans. Royal Society Open Science, 4, 161067. https://doi.org/10.1098/rsos.161067.

Ventola, C. L. (2011). The Antibiotic Resistance Crisis. Pharmacy and Therapeutics, 40, 277-283.

Vieno, N. M., Tuhkanen, T., \& Kronberg, L. (2005). Seasonal variation in the occurrence of pharmaceuticals in effluents from a sewage treatment plant and in the recipient water. Environmental Science \& Technology, 39, 8220-8226.

Vishlenkova, E. A. (2005). Do not drink water from Kaban! Environmental crisis at 19 th century Kazan. Native Land, 8, 94-96.

Wang, Y., Lu, J., Zhang, S., Mao, L., Yuan, Z., Bond, P., \& Guo, J. (2019). Non-antibiotic pharmaceuticals can enhance the spread of antibiotic resistance via conjugation. BioRix. https://doi.org/10.1101/724500.

Watkinson, A. J., Murby, E. J., \& Costanzo, S. D. (2007). Removal of antibiotics in conventional and advanced wastewater treatment: implications for environmental discharge and wastewater recycling. Water Research, 41, 4164-4176.

Watkinson, A. J., Murby, E. J., Kolpin, D. W., \& Costanzo, S. D. (2010). The occurrence of antibiotics in an urban watershed: from wastewater to drinking-water. Science of the Total Environment, 407, 2711-2723.

Wegener, H. (2003). Antibiotics in animal feed and their role in resistance development. Current Opinion in Microbiology, 6, 439-445.

Wegener, H. C. (2012). A15 Antibiotic resistance-linking human and animal health. In E. R. Choffnes, D. A. Relman, L. Olsen, R. Hutton, \& A. Mack (Eds.), Antibiotic resistance - Linking human And animal health: Improving food safety through a one health approach workshop summary. Washington DC: National Academies Press ISBN 978-0309-25937-8. NBK114485.

WHO. (2011). Guidelines for drinking-water quality (4th ed.). World Health Organization: Geneva.

Wilkinson J., and Boxall, A., (2019). The first global study of pharmaceutical contamination in riverine environments. SETAC Europe 29th Annual Meeting, Helsinki, May 28, 2019.

Woolhouse, M., Ward, M., van Bunnik, B., \& Farrar, J. (2015). Antimicrobial resistance in humans, livestock and the wider environment. Philosophical Transactions of the Royal Society B, 370(20), 140, 083. https://doi.org/10.1098 /rstb.2014.0083. 
World Health Organization (WHO) (2009). Global health risks. Mortality and burden of disease attributable to selected major risks. 70 pages. ISBN 97892 4,156,387 1. https://www.who. int/healthinfo/global_burden_disease/GlobalHealthRisks report full.pdf.

World Health Organization (WHO) (2011). Pharmaceuticals in drinking water. WHO/HSE/WSH/11.05 49 pages.

World Health Organization (WHO) (2015a). Antibiotic resistance http://www.who.int/mediacentre/factsheets/antibioticresistance/en/.

World Health Organization (WHO) (2015b). Global action plan on antimicrobial resistance. http://apps.who. int/iris/bitstream/10665/193736/1/9789241509763_eng.pdf.

World Health Organization (WHO) (2017). The world is running out of antibiotics, WHO report confirms. News release. https:/www.who.int/news-room/detail/20-09-2017-theworld-is-running-out-of-antibiotics-who-report-confirms.

Zaffiri, L., Gardner, J., \& Toledo-Pereyra, L. H. (2012). History of antibiotics. From Salvarsan to Cephalosporins. Journal of Investigative Surgery, 25, 67-77.

Zurek, L., \& Ghosh, A. (2014). Insects Represent a link between food animal farms and the urban environment for antibiotic resistance traits. Applied and Environmental Microbiology, 80, 3562-3567. https://doi.org/10.1128/AEM.00600-14.

Publisher's Note Springer Nature remains neutral with regard to jurisdictional claims in published maps and institutional affiliations. 